University of Wollongong

Research Online

Faculty of Science, Medicine and Health -

Papers: Part B

Faculty of Science, Medicine and Health

$1-1-2019$

\title{
Lachlan Orogen, Eastern Australia: Triangle Formation Records the Late Ordovician Arrival of the Macquarie Arc Terrane at the Margin of Eastern Gondwana
}

Q Zhang

University of Wollongong, qz576@uowmail.edu.au

Solomon Buckman

University of Wollongong, solomon@uow.edu.au

Vickie C. Bennett

Australian National University (ANU), vickie.bennett@anu.edu.au

Allen Phillip Nutman

University of Wollongong, anutman@uow.edu.au

Yang Song

Chinese Academy of Geological Sciences

Follow this and additional works at: https://ro.uow.edu.au/smhpapers1

Publication Details Citation

Zhang, Q., Buckman, S., Bennett, V. C., Nutman, A. P., \& Song, Y. (2019). Lachlan Orogen, Eastern Australia: Triangle Formation Records the Late Ordovician Arrival of the Macquarie Arc Terrane at the Margin of Eastern Gondwana. Faculty of Science, Medicine and Health - Papers: Part B. Retrieved from https://ro.uow.edu.au/smhpapers1/917 


\title{
Lachlan Orogen, Eastern Australia: Triangle Formation Records the Late Ordovician Arrival of the Macquarie Arc Terrane at the Margin of Eastern Gondwana
}

\author{
Abstract \\ The Ordovician intraoceanic Macquarie Arc terrane is faulted against coeval, quartz-rich turbidites of the \\ Adaminaby Group within the Lachlan Orogen of eastern Australia. Debates exist concerning the polarity of \\ subduction beneath the Macquarie Arc and the nature of its emplacement, given it is juxtaposed against \\ the Adaminaby Group to both the west and east. We present new provenance and zircon analyses of the \\ Triangle Formation, which consists of interleaved quartz-rich passive margin sandstones and island arc \\ volcaniclastic rocks. In contrast, the structurally underlying Adaminaby Group contains no volcaniclastic \\ detritus and displays a strong passive margin affinity. One sample from the Triangle Formation yielded a \\ youngest zircon age of $456 \pm 16 \mathrm{Ma}$ indicating a subtle Macquarie Arc signature among an \\ overwhelmingly Neoproterozoic and older Gondwanan provenance. The Adaminaby Group yielded a \\ youngest zircon age of $481 \pm 6 \mathrm{Ma}$ and a strong Gondwanan zircon signature. We compared these results \\ with volcaniclastic rocks from the Weemalla Formation stratigraphically higher in the Macquarie Arc, \\ which yielded a distinctly unimodal zircon age of $451 \pm 8 \mathrm{Ma}$, which is indistinguishable from the \\ youngest zircon in the Triangle Formation. We suggest the Triangle Formation represents trench fill \\ material sourced predominantly from the Gondwana margin but including some younger Macquarie Arc \\ detritus. This constrains the initiation of this arc-continent collision to between 448 and $462 \mathrm{Ma}$ (Late \\ Ordovician).

\section{Publication Details} \\ Zhang, Q., Buckman, S., Bennett, V. C., Nutman, A. \& Song, Y. (2019). Lachlan Orogen, Eastern Australia: \\ Triangle Formation Records the Late Ordovician Arrival of the Macquarie Arc Terrane at the Margin of \\ Eastern Gondwana. Tectonics, 38 (9), 3373-3393.
}




\section{Tectonics}

\section{RESEARCH ARTICLE 10.1029/2019TC005480 \\ Special Section: \\ Collisional orogenic systems as recorders of collisions between arc and continents}

Key Points:

- U-Pb-Hf zircon data and provenance analysis show that the Ordovician Triangle Formation has Macquarie Arc terrane and Gondwanan provenance

- The Triangle Formation formed in a trench fill setting, just prior to Macquarie Arc-Gondwana juxtaposition

- The youngest Triangle Formation zircon places this juxtaposition to after $\sim 456 \mathrm{Ma}$

Supporting Information:

- Supporting Information S1

- Data Set S1

Correspondence to:

Q. Zhang,

qz576@uowmail.edu.au

Citation:

Zhang, Q., Buckman, S., Bennett, V. C. Nutman, A., \& Song, Y. (2019). Lachlan Orogen, Eastern Australia: Triangle

Formation records the Late Ordovician arrival of the Macquarie Arc terrane at the margin of eastern Gondwana.

Tectonics, 38. https://doi.org/10.1029/ 2019TC005480

Received 4 JAN 2019

Accepted 16 AUG 2019

Accepted article online 21 AUG 2019

(C)2019. American Geophysical Union. All Rights Reserved.

\section{Lachlan Orogen, Eastern Australia: Triangle Formation Records the Late Ordovician Arrival of the Macquarie Arc Terrane at the Margin of Eastern Gondwana}

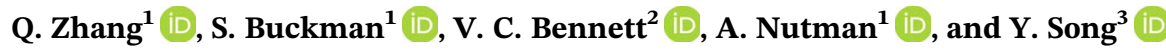 \\ ${ }^{1}$ School of Earth, Atmospheric and Life Sciences, University of Wollongong, Wollongong, New South Wales, Australia, \\ ${ }^{2}$ Research School of Earth Sciences, Australian National University, Canberra, ACT, Australia, ${ }^{3}$ Institute of Mineral \\ Resources, Chinese Academy of Geological Sciences, Beijing, China
}

Abstract The Ordovician intraoceanic Macquarie Arc terrane is faulted against coeval, quartz-rich turbidites of the Adaminaby Group within the Lachlan Orogen of eastern Australia. Debates exist concerning the polarity of subduction beneath the Macquarie Arc and the nature of its emplacement, given it is juxtaposed against the Adaminaby Group to both the west and east. We present new provenance and zircon analyses of the Triangle Formation, which consists of interleaved quartz-rich passive margin sandstones and island arc volcaniclastic rocks. In contrast, the structurally underlying Adaminaby Group contains no volcaniclastic detritus and displays a strong passive margin affinity. One sample from the Triangle Formation yielded a youngest zircon age of $456 \pm 16$ Ma indicating a subtle Macquarie Arc signature among an overwhelmingly Neoproterozoic and older Gondwanan provenance. The Adaminaby Group yielded a youngest zircon age of $481 \pm 6 \mathrm{Ma}$ and a strong Gondwanan zircon signature. We compared these results with volcaniclastic rocks from the Weemalla Formation stratigraphically higher in the Macquarie Arc, which yielded a distinctly unimodal zircon age of $451 \pm 8 \mathrm{Ma}$, which is indistinguishable from the youngest zircon in the Triangle Formation. We suggest the Triangle Formation represents trench fill material sourced predominantly from the Gondwana margin but including some younger Macquarie Arc detritus. This constrains the initiation of this arc-continent collision to between 448 and $462 \mathrm{Ma}$ (Late Ordovician).

Plain Language Summary Arc-continent collisions represent an important mechanism of continental growth. They can, however, be difficult to investigate because of overprinting deformation and erosion, which removes much of the evidence, particularly in older terranes. The Triangle Formation was deposited in a trench fill setting, shortly before the collision of the Ordovician Macquarie Arc with eastern Gondwana. It is dominated by continental and minor Macquarie Arc detritus, which is key to constraining the timing of the event. Thus, trench fill deposits potentially provide key constraints as to the timing and nature of arc-continent collisions.

\section{Introduction}

Arc-continent collisions are major orogen-forming events that can be complex but short-lived (Dewey, 2005). For example, collision of the Luzon Arc in northern Taiwan commenced only about 6.5 million years ago and is now experiencing orogenic collapse and subduction flip as the Ryuku trench accommodates subduction of the Philippine Sea Plate beneath the accreted Luzon Arc on the Eurasian margin (e.g., Huang et al., 2018). Changes in subduction polarity are evident at many convergent boundaries following arccontinent collisions (Von Hagke et al., 2016). However, many interpretations of ancient orogens assume that all convergence and continental growth were characterized by "normal" accretionary tectonics involving long-lived continuous subduction exclusively beneath the obvious continental margin (Cawood, 2005). This has been the predominant interpretation of the Macquarie Arc of southeast Australia for well over two decades (e.g., Collins, 2002; Glen et al., 1998). More recently, these models have been challenged and an alternative testable hypothesis of allochthonous arc-continent collision was proposed (Aitchison \& Buckman, 2012; Zhang et al., 2019). Under favorable conditions, with all such events, there should be a detrital record preserved in adjacent basins (e.g., Liuqu Conglomerate in Tibet; Davis et al., 2002). Our hypothesis is that similar, collision-related deposits with a mixed Macquarie Arc and Gondwana provenance exist within the latest Ordovician sequences of the Lachlan Orogen but are yet to be identified. 


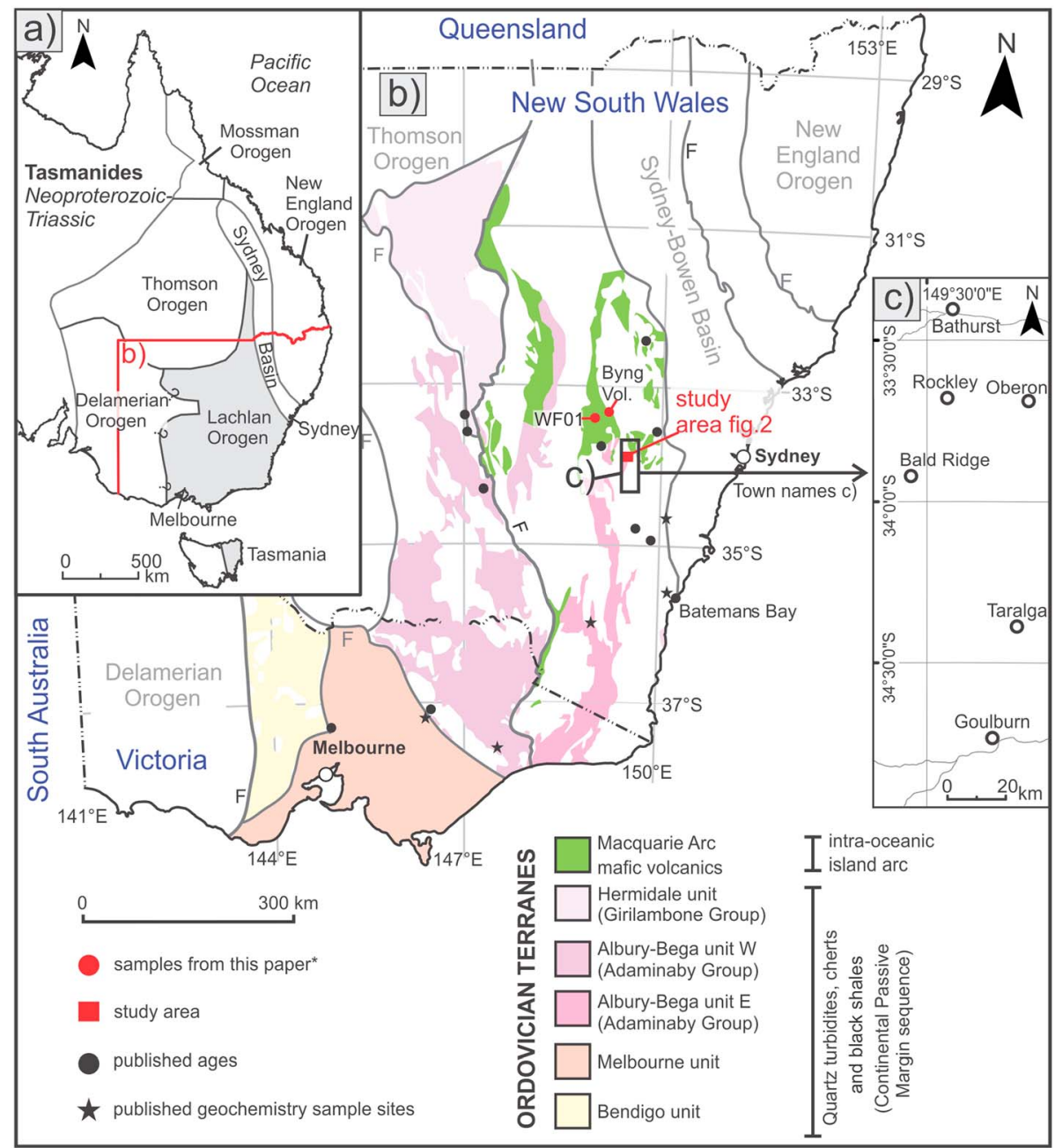

Figure 1. (a) Orogenic systems of the Tasmanides, eastern Australia (Glen, 2005, 2013). (b) Simplified geological map of the Lachlan Orogen in New South Wales and Victoria (after Colquhoun et al., 2017; Glen et al., 2009). *Samples WF01 of the Weemalla Formation, Byng Volcanics (detailed localities are presented in the supporting information Data Set S1) and samples from other publications are indicated. Our samples within "study area" (c) can be found in Figure 2. Sources of published ages can be found in Figure 3. The published geochemistry data sites are from Offler and Fergusson (2016). Abbreviations: Albury-Bega W \& E stand for the West and East Albury-Bega units, respectively; vol. = volcanics.

The Ordovician Macquarie Arc is a distinct island arc terrane within the Lachlan Orogen of eastern Australia (Crawford, Cooke, et al., 2007; Fergusson \& Colquhoun, 2018; Glen, Crawford, et al., 2007; Meffre et al., 2007). However, it is juxtaposed against coeval, mature, quartz-rich turbidites of the Adaminaby Group to both its west and east. The Adaminaby Group has a distinct Gondwanan, Cambro-Ordovician to Archean provenance (Figure 1; Fergusson et al., 2017; Glen et al., 2016, 2017). In contrast, detrital zircon provenance analyses of bona fide Macquarie Arc volcaniclastic rocks reveal an essentially Ordovician-only provenance with minimal Gondwanan inheritance (Zhang et al., 2019). Various models have been proposed to explain the juxtaposition of the Macquarie Arc as interleaved segments between the Adaminaby Group. These include (A) an episode of compression during long-lived, west dipping subduction (Cawood et al., 2009; Collins, 2002; Glen, 2013), (B) models with multiple subduction zones (Fergusson, 2003; Glen, Meffre, et al., 2007; Gray \& Foster, 2004; Meffre et al., 2007), (C) juxtaposition by strike-slip faulting (Glen et al., 2009; Meffre et al., 2007), (D) arc rotation followed by an orocline (Fergusson, 2009; Fergusson \& Colquhoun, 2018; Moresi et al., 2014), and (E) Aitchison and Buckman (2012) who proposed an arccontinent collision event as a result of east dipping subduction, before the allochthonous arc was emplaced onto the passive margin. Validation of any tectonic model requires accurate age and provenance data of 
coevel units from the continental margin, the arriving arc or ophiolite, and the trenchfill or postcollisional sedimentary units that may have mixed provenance.

The Macquarie Arc is dominated by basaltic andesite and associated volcaniclastic rocks (Crawford, Meffre, et al., 2007), and previous studies found almost no mixture of the Macquarie Arc and continental sediments (Colquhoun et al., 1999; Meffre et al., 2007). However, the Triangle Formation, which is assigned to the Macquarie Arc (Percival \& Glen, 2007), has been described as containing both quartz-rich sands (e.g., Fergusson \& VandenBerg, 1990) and volcaniclastic grains (e.g., Fergusson \& Colquhoun, 1996; Glen, Meffre, et al., 2007; Murray \& Stewart, 2001), but these are from different outcrops. In this study, we focus on the Ordovician Triangle Formation as a possible candidate for trench fill to the Macquarie Arc, formed shortly before the terrane arrived on the eastern margin of Gondwana. The study involves field investigation, petrography, whole rock geochemistry, and zircon $\mathrm{U}-\mathrm{Pb}-\mathrm{Hf}$ isotopic analyses of both the Triangle Formation and the adjacent Adaminaby Group strata at Bald Ridge, $\sim 53 \mathrm{~km}$ southwest of Bathurst, New South Wales (Figures 1 and 2). These results constrain the timing of collision of the Macquarie Arc with eastern Gondwana.

\section{Regional Geological Setting}

The Tasmanides represent the Palaeozoic accretionary growth of Gondwana's eastern margin and include five orogenic belts (Figure 1a; Glen, 2013). This study focuses on the Lachlan Orogen (Figure 1b; Gray \& Foster, 2004), which consists of Ordovician to Carboniferous rocks, with some localized Cambrian greenstones. The Lachlan Orogen is dominated by the Ordovician Macquarie Arc and four coeval continental margin units collectively referred to as the Adaminaby Group (based on the bounding structures and metamorphic grade). From west to east, the Adaminaby Group includes the Bendigo, Melbourne, Albury-Bega, and Hermidale in the north (Figure 1b; Fergusson et al., 1986; Glen, 1992; Glen et al., 2009; Leitch \& Scheibner, 1987; VandenBerg \& Stewart, 1992). The Albury-Bega unit has been divided into western and eastern parts, which are in tectonic contact on the western and eastern sides of the Macquarie Arc (Figures 1b and 3; Glen et al., 2009). The Macquarie Arc mainly consists of mafic to intermediate volcanic and volcaniclastic rocks (Crawford et al., 1997; Glen, Crawford, et al., 2007; Glen et al., 1998). The Albury-Bega unit is dominated by Early to Middle Ordovician turbiditic quartz-rich sandstones of the Adaminaby Group, with the Late Ordovician chert, siltstone, and black shales of the Bendoc Group (Figure 3; Glen, 2005; Glen et al., 2009). The Middle to Late Ordovician Triangle Formation is less extensive than the Adaminaby Group and consists of both volcaniclastic rocks and quartz-rich turbidites (Fergusson \& VandenBerg, 1990; Percival \& Glen, 2007). It generally crops out between rocks ascribed to the Adaminaby Group and the Macquarie Arc but was assigned as one of the oldest Middle Ordovician units of the Macquarie Arc (Percival \& Glen, 2007; Pogson \& Watkins, 1998).

\section{Geology of the Bald Ridge Study Area}

At Bald Ridge, the highly deformed Adaminaby Group forms the core of an anticline, and the overlying Triangle Formation is separated from it by a tectonized unit of mafic-ultramafic actinolite schist which is locally incorporated into a mélange containing blocks of quartzite (Pogson \& Watkins, 1998; Figures 2a and $2 \mathrm{~b}$ ). Silurian volcanic and volcaniclastic rocks unconformably overlay the Triangle Formation and have been folded to form a broad N-S trending anticline (Figure 2a). Subsequent tectonism has resulted in faulting along the unconformable contact between the Silurian and Ordovician rocks (Figure 2b). Cleavages with a NNE-SSW strike, dipping at $60-80^{\circ} \mathrm{W}$ (Figure $2 \mathrm{~b}$ and supporting information Figure S1), occur in both the Silurian and Ordovician units. The closest Macquarie Arc volcanic rocks to the Triangle Formation are the Rockley Volcanics. They occur in the northeast of the area, separated from the Silurian unit by a postSilurian fault (Figure 2a).

The metamorphic rocks that occur between the Adaminaby Group and Triangle Formation are highly sheared to upper greenschist facies actinolite-talc schists from a mafic to ultramafic protolith (Pogson \& Watkins, 1998). The shear zone deformation at the contact between the Triangle Formation and the underlying Adaminaby Group does not penetrate far into the footwall. Only the upper part of the thick turbidite unit has been strongly deformed with vertical foliations cutting through the bedding, whereas the lower part is better preserved (Figures $2 \mathrm{~d}$ and $\mathrm{S} 2 \mathrm{a}$ ). Shear fabrics extend into the hanging wall of the Triangle 

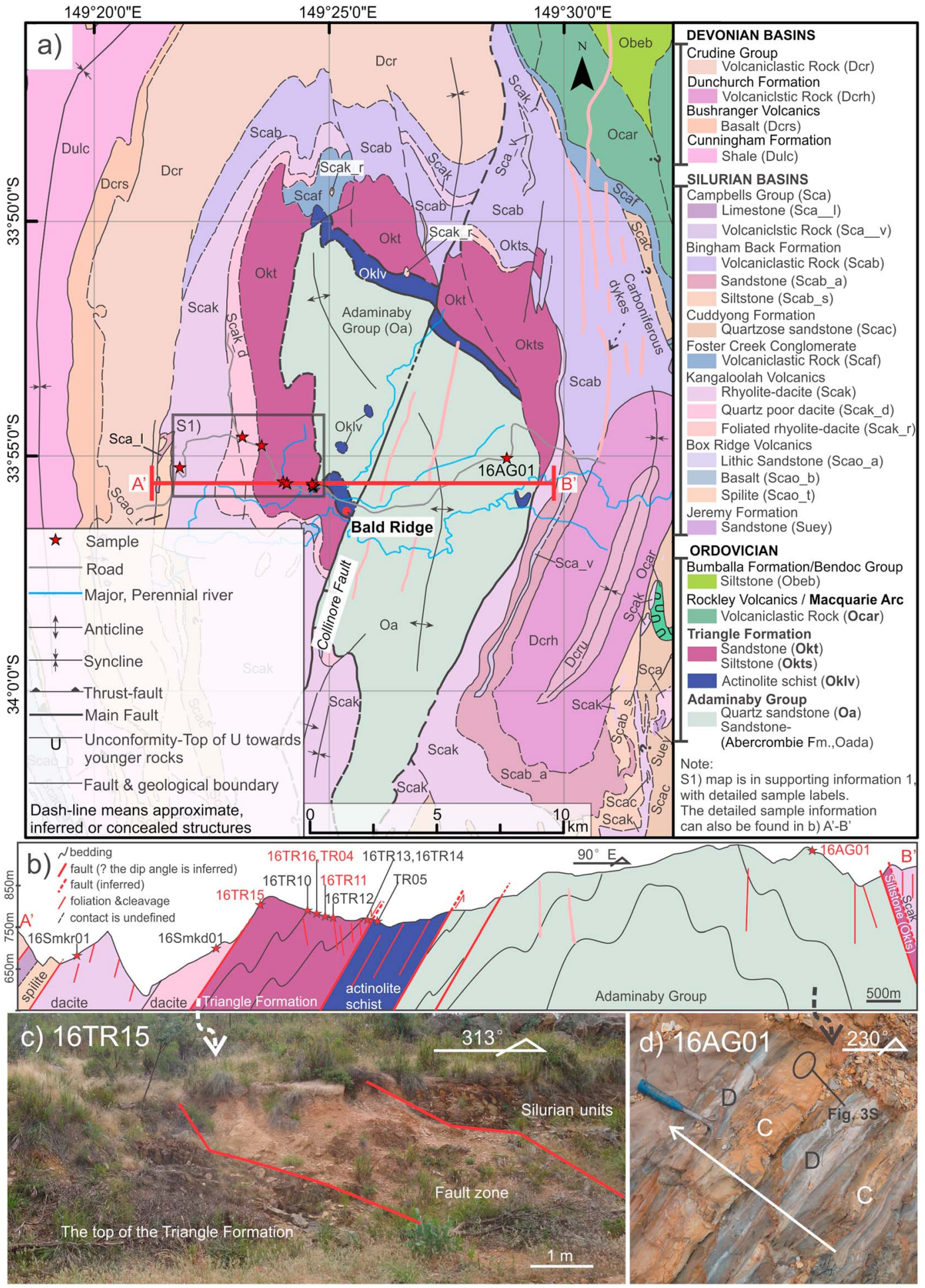

Figure 2. (a, b) Geological map of the Bald Ridge area (revised on Colquhoun et al., 2017) with a transect $\mathrm{A}^{\prime}-\mathrm{B}^{\prime}$. Detailed sample localities are in the supporting information Figure S1. Most structural data on (b) are after Colquhoun et al. (2017). (c) Fault contact between the Triangle Formation and Silurian dacite. Samples 16TR15 (quartz-rich sandstone) and 16TR15-1 (feldspar-rich volcaniclastic rock) are from the top of the Triangle Formation with the boundary between these two lithologies not exposed ( $\left.33^{\circ} 54^{\prime} 46.94^{\prime \prime} \mathrm{S}, 149^{\circ} 23^{\prime} 32.39^{\prime \prime} \mathrm{E}\right)$. (d) Less deformed Adaminaby Group shows Bouma sequence: "C"-fine-grained sandstone with cross laminations and ripples (detailed photographs are presented in Figure 3S), "D" - parallel-laminated siltstone $\left(33^{\circ} 55^{\prime} 2.69^{\prime \prime} \mathrm{S}, 149^{\circ} 28^{\prime} 45.74^{\prime \prime} \mathrm{E}\right)$. The white arrow in (d) indicates the younging direction. The dashed arrow lines in (c, d) indicate the field photographs' locations in the transect. 


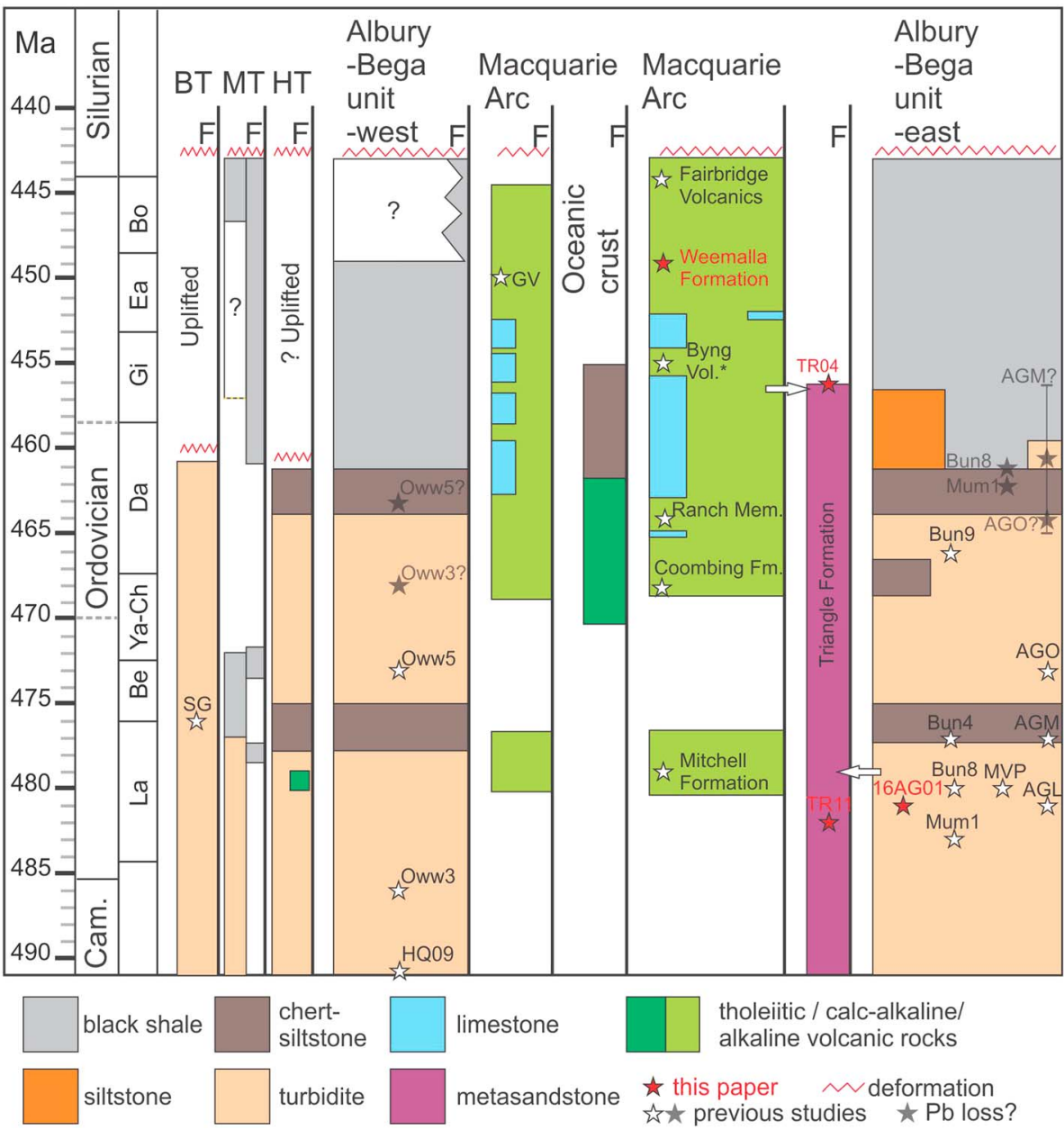

Figure 3. Composite stratigraphic columns of the Lachlan Orogen (after Glen et al., 2017). Sources of published ages: SGSunbury Group (Squire et al., 2006); Oww3, Oww5, Bun4, Bun8, Bun9, and Mum1 (Glen et al., 2017); HQ09 and MVP (Fergusson et al., 2013); AGO, AGL, AGM, and Coombing Formation (Meffre et al., 2007); Mitchell Formation and part of the Fairbridge Volcanics (Zhang et al., 2019); other Fairbridge Volcanics data and the Ranch member (Glen et al., 2011). *Byng Volcanics age is after Crawford, Meffre, et al. (2007), and the geochemistry analysis is from this study. The leftand right-side horizontal white arrows represent the contribution of the Macquarie Arc and the Adaminaby Group to the Triangle Formation, respectively. Abbreviations: Mem = Member; Fm = Formation; GV = Goonumbla Volcanics; F = fault; $\mathrm{BT}=$ Bendigo unit; $\mathrm{MT}=$ Melbourne unit; $\mathrm{HT}=$ Hermidale unit; Australian stages of the Ordovician $=$ Bolindian, Eastonian, Gisbornian, Darriwilian, Yapeenian-Chewtonian, Bendigonian, Lancefieldian.

Formation (Figure 2b) and in places a mud-matrix mélange containing massive blocks of actinolite/tremolite-talc schist has developed between the two units (Figure S2b). In the middle part of the Triangle Formation, deformation is weaker, while deformation in the upper section is affected by faulting along the unconformable contact between the Ordovician and Silurian units (Figure 2c).

The Adaminaby Group in the Bald Ridge area shows Bouma sequence "C" (fine-grained sandstone ripples) and "D" (siltstone) units (Figures 2d and S3), indicating a marine fan environment (Bouma, 1962; Sengör \& Natal'In, 1996). The absence of course-grained Bouma "A" horizon unit suggests that these are distal deposits. The Adaminaby Group is $\geq 1,000 \mathrm{~m}$ thick, but the nature of the underlying basement rocks is unresolved (Fergusson \& Fanning, 2002; Pogson \& Watkins, 1998; Thomas \& Pogson, 2012). The turbidite unit age has been assigned to be older than late Darriwilian ( $462 \mathrm{Ma}$; Figure 3), as constrained by the fossil assemblages in the overlying Bendoc Group (Fergusson \& Colquhoun, 2018, and references therein).

The Triangle Formation-type section is located south of Rockley (Figure 1c) and was first described by Stanton (1956) as a succession of shales, sandstone, chert, and tuff, dominated by siltstone and feldspathic 
volcaniclastic rocks. Subsequent studies in the Rockley area reported that this unit is dominated by quartzpoor feldspathic volcaniclastic rocks, which are overlain by the Rockley Volcanics (eastern part of the Macquarie Arc rocks; Fergusson \& Colquhoun, 1996; Fergusson \& VandenBerg, 1990; Glen, Meffre, et al., 2007; Murray \& Stewart, 2001; Percival \& Glen, 2007). Fowler and Iwata (1995) described the Triangle Formation as a sandwich-type assemblage with quartz-rich siltstone and chert on the top and bottom and $1,200 \mathrm{~m}$ of mafic feldspathic arenites in the middle. In the Goulburn area (Figure 1c), both quartzose and lithic greywackes have been reported (Fergusson \& VandenBerg, 1990; Offenberg, 1974). Fowler and Iwata (1995) reported conodont assemblages from the upper part of the Triangle Formation in Rockley area, which indicated ages ranging from late Darriwilian to early Gisbornian (Middle to early-Late Ordovician). Murray and Stewart (2001) reported the same Darriwilian to Gisbornian conodont assemblages, aside from one sample containing Bendigonian (Early Ordovician) fossils. However, Percival et al. (2011) suggested that these fossils are from an Ordovician clast and that the Triangle Formation is a Siluro-Devonian unit with exotic blocks of Ordovician chert and Silurian limestone, but they emphasized that the confusing mixture of Ordovician and Silurian fossil ages from the Triangle Formation requires a complete reappraisal of the regional geology. In the updated seamless New South Wales geology map, the Triangle Formation is also marked as a Silurian unit in the Bald Ridge area (Colquhoun et al., 2017) but a Silurian age is not supported by our detrital zircon data.

In the Bald Ridge area, the lower part of the Triangle Formation is dominated by quartz-rich metasandstones (Figures $4 \mathrm{~b}$ and $4 \mathrm{c}$ ). In the top of the formation, medium-fine-grained volcaniclastic rocks are dominated by feldspar fragments (Figure 4d). The overall thickness of the Triangle Formation was estimated at $\sim 1,000 \mathrm{~m}$ in the Bald Ridge area (Pogson \& Watkins, 1998; Stanton, 1956).

\section{Samples and Petrography}

Representative photomicrographs of the Adaminaby Group (16AG01), Triangle Formation (16TR15-16), mafic schist (TR05B, C), Silurian units (16Smkr01), and Macquarie Arc samples (16GV01-Goonumbla Volcanics) are shown in Figure 4. Images of rock samples and other photomicrographs discussed in the text are present in the supporting information Figures S2-S5. Sample localities are presented in the supporting information Data Set S1. Sample 16AG01 from the Adaminaby Group Bouma C sequence turbidite (Figures $2 \mathrm{~d}$ and S3) is a fine-grained quartz-rich metasandstone, dominated by quartz grains $(\leq 0.1 \mathrm{~mm})$ and $\sim 5 \%$ muscovite (Figure 4a). Samples 16TR10-15 and 16TR16 are quartz-rich metasandstone of biotite grade (e.g., Figures 4b and 4c). Stronger deformation in 16TR15 is shown by more quartz recrystallization. Sample 16TR15-1 is feldspar-rich volcaniclastic rock dominated by K-feldspar and plagioclase fragments, with muscovite + chlorite + biotite matrix showing the foliation (Figure 4d). Mafic schists crop out at the boundary between the Adaminaby Group and the Triangle Formation. There are two types of schist: actinolite schist (e.g., TR05B) and tremolite-talc schist (e.g., TR05A, C; Figures S4a and S4b). TR05B is dominated by actinolite and some quartz + chlorite + apatite (Figure 4e), and TR05C has a mineral assemblage of tremolite + talc + Ti-rich pyroxene (Figures $4 \mathrm{f}$ and S6 and Data Set S2). The mafic schist mineral assemblages indicate a metamorphic grade of upper greenschist facies. Samples 16Smkr and 16Smkd are of foliated Silurian dacite that overlie the Triangle Formation. They display quartz and feldspar phenocrysts and muscovite + chlorite in a schistose matrix (Figures $4 \mathrm{~g}$ and S5c). Quartz recrystallization is more common in 16Smkr. Samples WF01 (Weemalla Formation), 16GV01 (Goonumbla Volcanics), 16MF01 (Mitchell Formation), and 16FV01Sa (Fairbridge Volcanics) are from the Macquarie Arc (Figure 3). Sample WF01 is a fine-grained volcaniclastic rock/tuff (Figure S5d). Samples 16GV01 and 16MF01 are volcaniclastic rocks, dominated by lithic and some feldspar clasts (Figures $4 \mathrm{~h}$ and S5e). Sample 16FV01Sa is dominated by feldspar clasts (Figure S5f).

Representative samples of the Adaminaby Group (16AG01), Triangle Formation (16TR10, 11, 15-1), and the Macquarie Arc (16MF01, 16GV01-02, and 16FV01Sa) were point counted. The relative content of quartz (Q), feldspar (F), and lithic fragments (L) are shown in a QFL diagram (Dickinson, 1985; Figure 5a; the data are presented in the supporting information Data Set S3). The Adaminaby Group sample plots in the craton interior field, whereas samples from the upper part of the Triangle Formation fall in the recycled orogenic field, and samples from stratigraphically lower within this formation fall in the arc setting, similar to the 

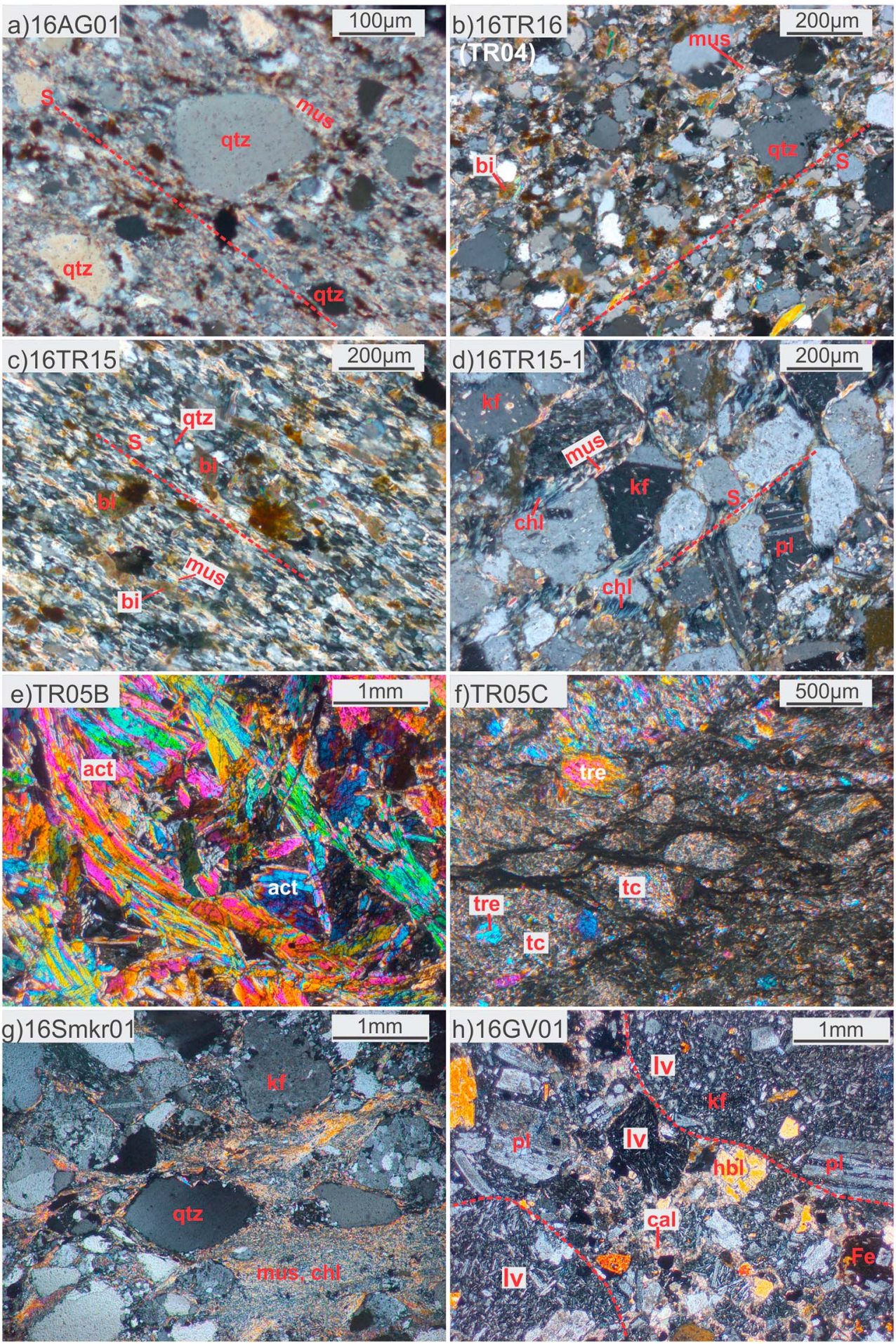

Figure 4. Photomicrographs under crossed nicols. (a, b, c) Fine-grained quartz-rich metasandstone of the Adaminaby Group (a) and Triangle Formation (b, c). In (a), the sericite and oriented quartz indicate a foliation, in (b) partly recrystallized quartz, sericite, and biotite show the foliation, and in (c) the recrystallized quartz grains and oriented sericite and biotite indicate the foliation. From (a) to (c), the changes of mineral assemblage and texture indicate that the deformation is stronger. (d) Feldspar-rich sandstone of the Triangle Formation. The foliation is mainly indicated by the sericite, chlorite, and biotite. (e) Mafic actinolite schist. (f) Mafic tremolite-talc schist with mud matrix. (g) Foliated Silurian dacite with oriented quartz, plagioclase and k-feldspar phenocrysts, and sericite + chlorite in the matrix showing a schistose texture. (h) Lithic volcaniclastic sandstone of the Goonumbla Volcanics of the Macquarie Arc with andesitic clasts, feldspars $(\mathrm{pl}+\mathrm{kf})$, hornblende, calcite, and Fe-oxide. Thin section of TR05B (e) thickness is at $\sim 45 \mathrm{~mm}$. Other samples have a thickness of $\sim 40 \mathrm{~mm}$. Abbreviations: qtz $=$

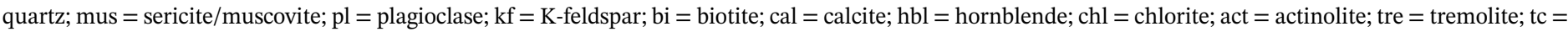
talc; lv = lithic volcanic-clast; Fe-Fe-oxide; $\mathrm{S}$ with a dash-line $=$ foliation/orientation of the foliated minerals. 

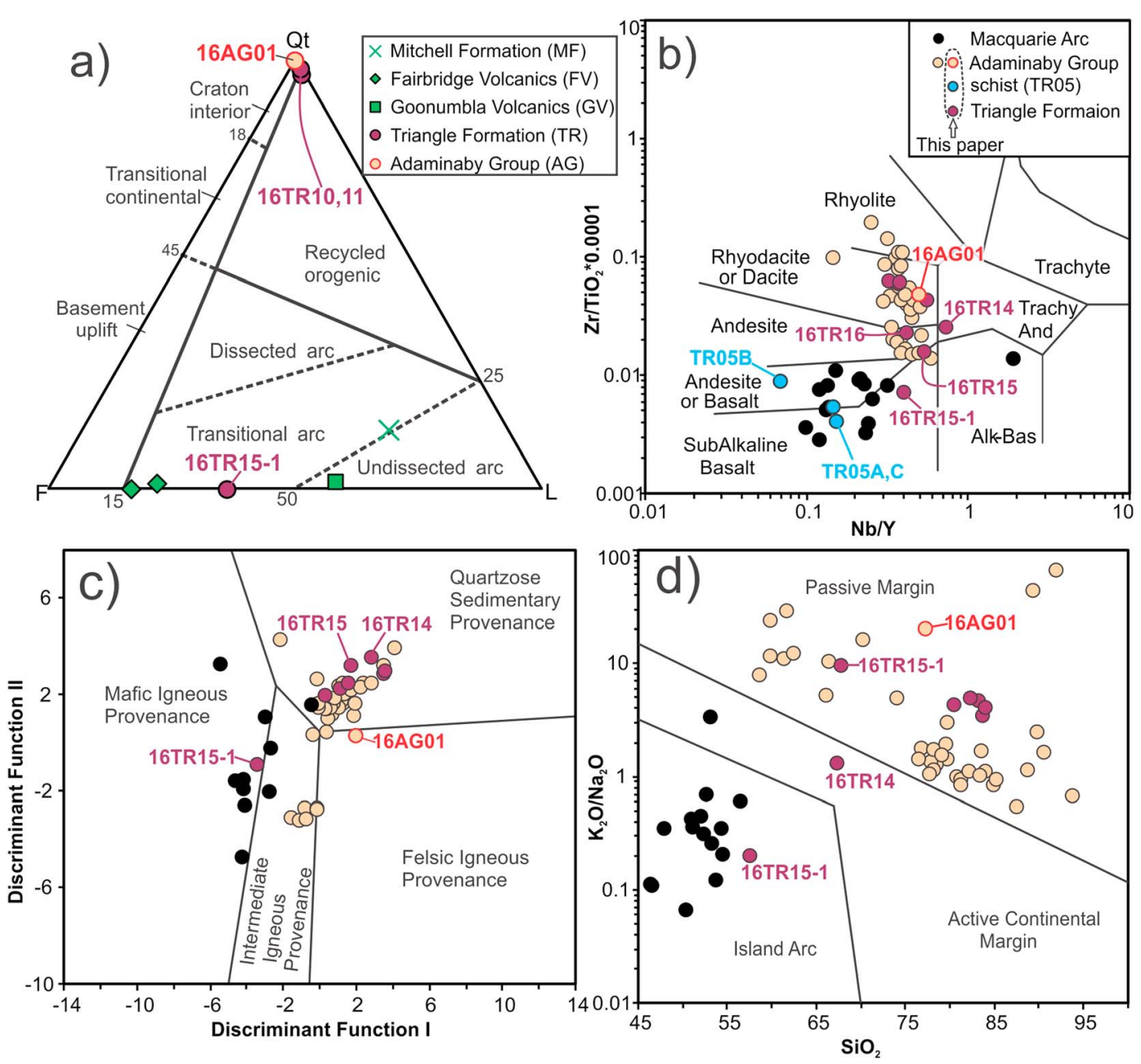

Figure 5. Lithology and whole rock geochemistry results. (a) Qt-F-L triangle plot after Dickinson (1985). The same symbols for samples are used in plots b, c, and d.

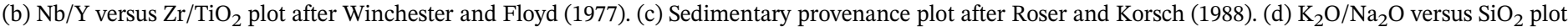
for tectonic setting after Roser and Korsch (1986). Geochemistry data sources of plots b, c, and d: 16AG01, TR05A-C, and 16TR10-16 are from this study; Macquarie Arc samples are from Zhang et al. (2019), and other Adaminaby Group samples are from Offler and Fergusson (2016).

Macquarie Arc samples (corresponding to the Michell Formation plus Fairbridge and Goonumbla volcanics).

\section{Analytical Methods}

Coarser-grained samples 16AG01 from the Adaminaby Group, TR04 (16TR16) and 16TR11 from the middle levels of the Triangle Formation, $16 \mathrm{Smkr}$ and 16Smkd from the Silurian dacite, and WF01 from the Weemalla Formation of the Macquarie Arc were chosen as representative samples for zircon U-Pb dating. Hf isotopic analyses were undertaken on zircons from samples TR04, 16TR11, and WF01. The least altered samples 16AG01 and 16TR10-16 across transect A'-B' (Figure 2b) were selected to compare their whole rock geochemistry with the Macquarie Arc volcanic rocks. Four relatively unaltered Byng Volcanics samples (16BY11, 11i, 12, and 13) were employed for whole rock geochemistry as the representative volcanic rocks of the Macquarie Arc.

\subsection{Zircon U-Pb Isotopic Dating}

Apart from sample 16AG01, all zircon separations were undertaken at the Institute of Hebei Regional Geological Survey, China (details are presented in the supporting information Text S1). Sample 16AG01 was processed at Australia National University (ANU) using standard heavy liquid and isodynamic 
separation techniques. Zircons were handpicked under a binocular microscope and were mounted in epoxy discs together with Temora 2 standard zircons. The zircon mounts were then polished, prior to cathodoluminescence (CL) imaging. The CL images were obtained via the Scanning Microscope JSM-6490 MonoCL4 at the Electron Microscopy Centre, University of Wollongong.

Zircon U-Pb analyses of samples 16AG01, 16Smkr, and 16Smkd were conducted by laser ablationinductively coupled plasma mass spectrometry (LA-ICP-MS) with a New Wave ESI 193-nm laser ablation system and Thermo ELEMET XR high-resolution mass spectrometer, at the National Research Center of Geoanalysis, China. After every 10 unknown grains, a group of standard zircons, including two GJ-1 (609 Ma; Jackson et al., 2004) and one Plesovice (337 Ma; Sláma et al., 2008), were analyzed. The raw data were processed using the program Glitter (Version 4.0; Van Achterbergh et al., 2001). Analyzed results including standard zircons, more detailed parameters, and procedures are presented in the supporting information Data Set S4.

Samples WF01, TR04, 16TR11, and nine zircon grains from 16AG01 (eight of them are for multiple analyses on the youngest grains based on the LA-ICP-MS result), were analyzed on the SHRIMP-RG instrument at ANU, following the protocols of Williams (1998). Standard zircon Temora 2 (417 Ma; Black et al., 2003) was distributed as several clusters of grains in different parts of the epoxy mounts. They were analyzed in a random fashion between every three unknown grain analyses. The raw data for samples WF01 and TR04 were reduced and calibrated using the previous ANU OS9 applications PRAWN and LEAD, while samples 16AG01 and 16TR11 were reduced and calibrated using the windows-based POXI-SC application developed by ANU. The results and more details of the method are in the supporting information Data Set S5 (based on Compston et al., 1984; Cumming \& Richards, 1975). Reduced data were assessed and visualized using Isoplot 4.1 (Ludwig, 2003), and all weighted mean ages are reported at the 95\% confidence level.

\subsection{Zircon Lu-Hf Isotope Analyses}

Zircon Hf isotopic compositions were carried out on the RSES ThermoFinnigan Neptune multicollector ICPMS with 193-nm excimer laser system at ANU using the methods of Hiess et al. (2009). The laser pulsed at 5 $\mathrm{Hz}$ with energy density of $\sim 10 \mathrm{~J} / \mathrm{cm}^{2}$ with a $42 \times 42-\mu \mathrm{m}$ beam. A gas blank and a suite of five reference zircons with varying REE contents (Monastery, Mud Tank, FC1, Plesovice and QGNG; Sláma et al., 2008; Woodhead \& Hergt, 2005) were analyzed after every 10-15 unknown sample spots throughout the session as quality control monitors. The Lu-Hf isotopic compositions for CHUR used for calculation of epsilon values are from Bouvier et al. (2008). A more detailed method description and complete Lu-Hf isotopic data, including the reference zircon analyses, are presented in the supporting information Data Sets S6 and S7.

\subsection{Whole Rock Major and Trace Geochemistry}

Representative samples of the Adaminaby Group (16AG01), Triangle Formation (16TR10-16), mafic schist (TR05A-C), and Byng Volcanics (16BY11-13) were crushed using a chromium steel TEMA ring mill. The major element analyses were conducted using Spectro (XEPOS) X-Ray fluorescence spectrometer at University of Wollongong, following the protocols of Norrish and Chappell (1977). The trace elements were analyzed at ALS Mineral Division, Brisbane. Samples 16AG01, 16TR10-14, and WF01 were analyzed via ICP-MS. Samples 16TR15-16 (including 16TR15-1) and 16BY11-13 were analyzed via ICP-AES and ICPMS. Details of the methods and results are presented in the supporting information Data Set S8. The data were plotted using Geokit (Lu, 2004).

\section{Whole Rock Major and Trace Element Geochemistry}

Data from the Adaminaby Group and Triangle Formation samples were plotted on the $\mathrm{Nb} / \mathrm{Y}-\mathrm{Zr} / \mathrm{TiO}{ }_{2}$ diagram to determine the geochemical affinity of the source rocks (Figure 5b). The Adaminaby Group sample 16AG01 and most Triangle Formation samples (except 16TR14-16) are dominated by rhyolite/dacite sources. The source is similar to most of the Adaminaby Group sandstones, which were reported by Offler and Fergusson (2016; Figure 5b). Samples 16TR14, 15, and 16 fall in the trachyandesite and andesite fields, and sample 16TR15-1 is in the basalt area, indicating that they have more intermediate and mafic sources, respectively. In the sedimentary provenance discrimination diagram (Figure 5c), the Adaminaby Group sample 16AG01 plots in the felsic igneous provenance area. Most Triangle Formation samples lay in the quartzose sedimentary provenance field, except 16TR15-1, which displays a mafic igneous provenance. In 

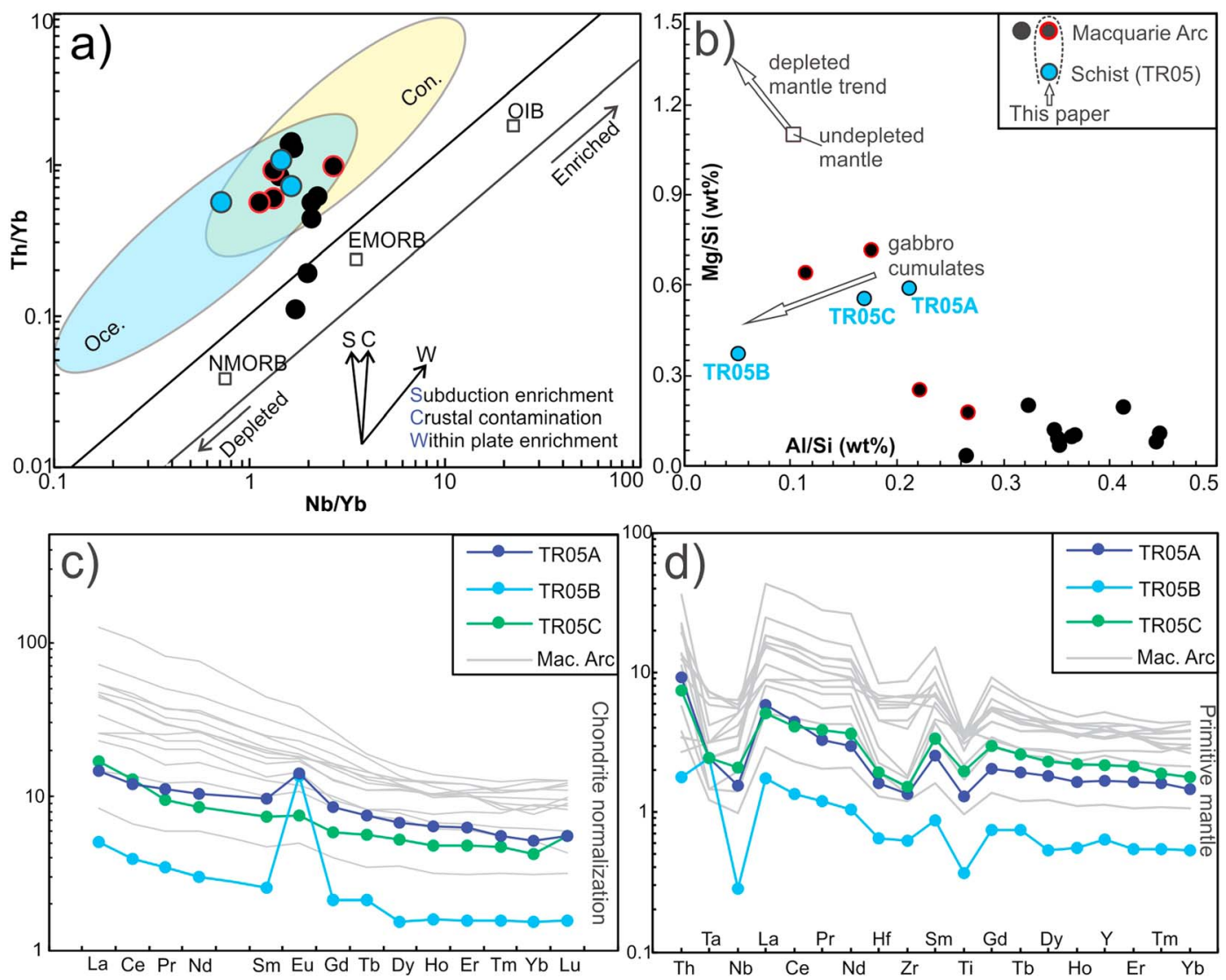

Figure 6. Geochemistry of the mafic schist samples (TR05 A, B, C). The same symbols for samples are used in (a, b). (a) Nb/Yb versus Th/Yb plot after Pearce (1982). (b) $\mathrm{Al} / \mathrm{Si}$ (wt\%) versus $\mathrm{Mg} / \mathrm{Si}$ (wt\%) plot. The primitive to depleted mantle trend line is based on the data from Jagoutz et al. (1979) and Taylor and

McLennan (1981), and the gabbro cumulate is after Nutman et al. (2009). (c) Chondrite normalized REE diagram. (d) Primitive Mantle normalized immobile trace element diagram. Normalizing values in (c, d) are from Sun and McDonough (1989). In (a-d), four Macquarie Arc samples are from this study and others are from Zhang et al. (2019).

the tectonic setting diagram (Figure 5d), Adaminaby Group sample 16AG01 sits in the passive margin field, while the Triangle Formation samples are mostly in the passive margin area, but 16TR14 and 16TR15-1 plot in the active margin and island arc fields, respectively.

To determine whether the mafic schist samples (TR05A-C) are sourced from the mantle or the Macquarie Arc crustal rocks, $\mathrm{Th} / \mathrm{Yb}-\mathrm{Nb} / \mathrm{Yb}$ and $\mathrm{Mg} / \mathrm{Si}-\mathrm{Al} / \mathrm{Si}$ diagrams are used, with indications of tectonic settings and mantle depletion trend, respectively (Figures $6 \mathrm{a}$ and $6 \mathrm{~b}$ ). In the tectonic setting diagram (Figure 6a), they plot above the MORB-OIB array, in the field of arc rocks. In the $\mathrm{Mg} / \mathrm{Si}-\mathrm{Al} / \mathrm{Si}$ diagram (Figure $6 \mathrm{~b}$ ), the schist samples form an array with $\mathrm{Mg} / \mathrm{Si}$ much lower than the depleted mantle trend. To further compare the mafic schist and Macquarie Arc samples, the chondrite normalized REE diagram shows that the mafic schists have low $\Sigma$ REE and positive Eu anomalies, especially the actinolite schist (TR05B; Figure 6c). The $(\mathrm{La} / \mathrm{Yb}) \mathrm{N}$ values at 2.89-3.98 indicate that the schist samples are slightly enriched in LREE (values are presented in Data Set S8). The primitive mantle-normalized spider diagram indicates that the tremolite-talc schist samples (TR05A, C) have negative Nb, Ta, Zr, Hf, and Ti anomalies (Figure 6d). The actinolite schist sample (TR05B) has lower overall trace element contents and strongly negative $\mathrm{Nb}$ anomaly (Figure 6d).

\section{Zircon U-Pb Analyses}

\subsection{Adaminaby Group (16AG01)}

Some zircons with prismatic shapes were well preserved with slight abrasion, while others are abraded and clearly eroded. Eighty-four zircon grains from 16AG01 were analyzed on LA-ICP-MS, with the eight "youngest" ${ }^{206} \mathrm{~Pb} /{ }^{238} \mathrm{U}$ ages at $448-484 \mathrm{Ma}$. These "young" grains have been reanalyzed on SHRIMP-RG, with the 


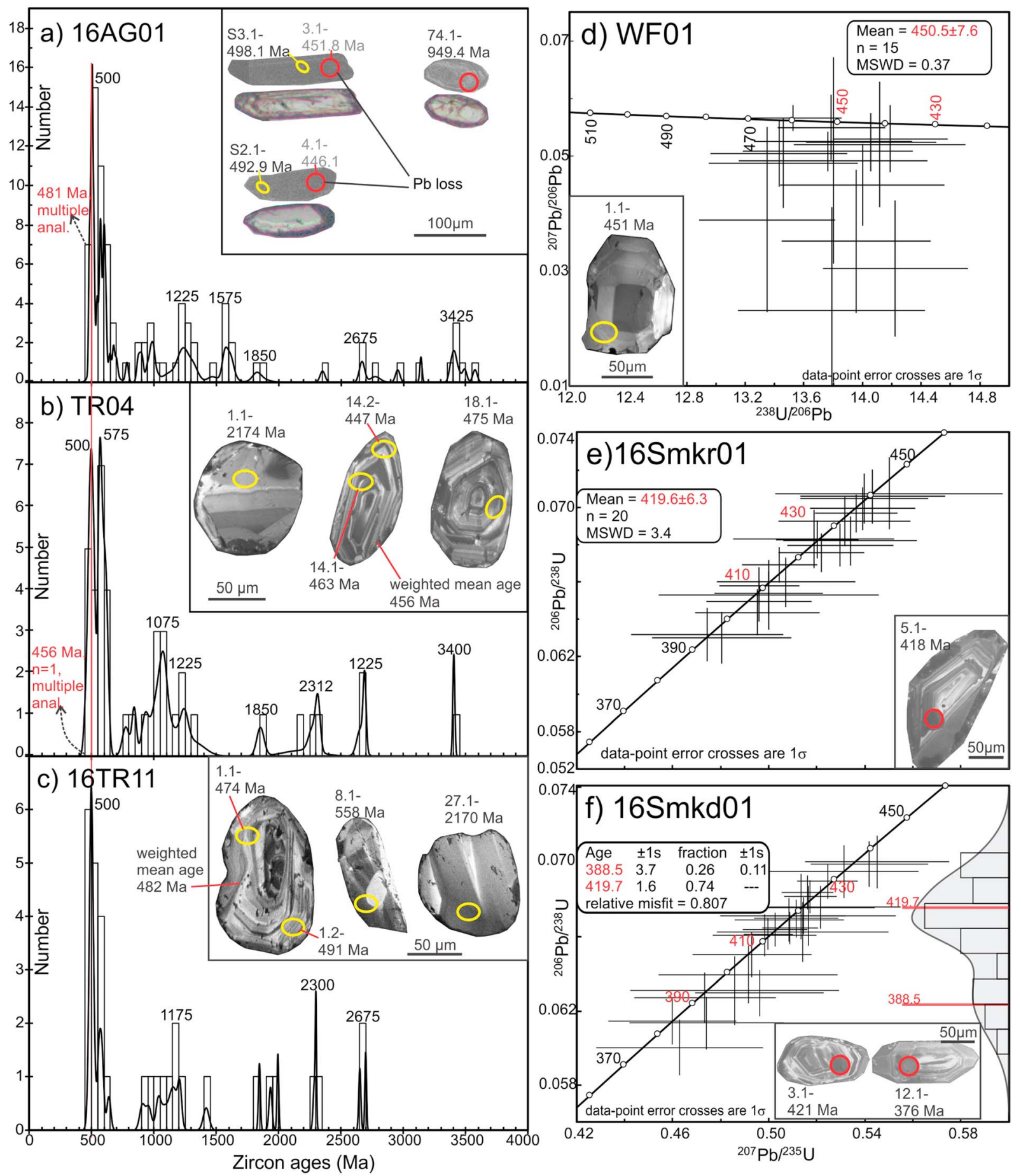

Figure 7. Zircon U-Pb age results with representative zircon CL images (see more CL images of sample TR04 and WF01 in Figures S7 and S8). The yellow circles marked on CL images are SHRIMP analysis spots, and red circles are via LA-ICPMS. (a) 16AG01 has the youngest zircon age at 481 Ma, (b) TR04 has the youngest zircon age at $456 \mathrm{Ma}$, (c) 16TR11 has the youngest zircon age at $482 \mathrm{Ma}$, (d) WF01 has the weighted mean age at 450.5 Ma, (e) 16Smkr has the weighted mean age at $419.6 \mathrm{Ma}$, (f) 16Smkd01 has two peak ages at 388.5 and 419.7 Ma. The younger peak at 388 Ma may represent the recrystallization age corresponding to the post-Silurian deformation event.

new result of ${ }^{206} \mathrm{~Pb} /{ }^{238} \mathrm{U}$ ages ranging from 481 to $521 \mathrm{Ma}$. The youngest two grains, analyzed as being 446 and $451 \mathrm{Ma}$ in age by LA-ICP-MS, when reanalyzed on the SHRIMP have ages of 492 and $498 \mathrm{Ma}$, respectively (see the representative CL images in Figure 7a). Thus, the youngest LA-ICP-MS ages are 
probably due to $\mathrm{Pb}$ loss and will not be considered further here. Overall, the most reliable ages indicate that the youngest grain of 16AG01 is $481 \mathrm{Ma}$, with other age peaks at 500 and 1000-1575 Ma and a few Archean grains (Figure 7a).

\subsection{Triangle Formation (TR04 and 16TR11)}

The Ordovician and Cambrian zircons are relatively well preserved showing prismatic shapes with zonings parallel to grain exteriors (Figures $7 \mathrm{~b}$ and S7). Sample TR04 has a youngest grain of $456 \pm 16$ Ma which was analyzed by SHRIMP. This is the weighted mean age of two analyses on one grain ( $463 \pm 10$ and $447.1 \pm 12.9$ Ma). Other peak ages of this sample occur at 500-575 and 1075-1225 Ma and a few earlier Precambrian grains (Figure 7b). The youngest grain of sample 16TR11 is $482 \mathrm{Ma}$, with other age peaks at 500 and 1175 Ma and a few earlier Precambrian grains (Figure 7c).

\subsection{Weemalla Formation, Macquarie Arc (WF01)}

Both short and prismatic zircon fragments display wide zonation (Figure 7d; see more CL images in Figure S8). WF01 zircons have low to undetectable common $\mathrm{Pb}$ and $\mathrm{Th} / \mathrm{U}$ ratios of 0.39 to 0.79 . All analyses yield a weighted mean ${ }^{206} \mathrm{~Pb} /{ }^{238} \mathrm{U}$ age of $450.5 \pm 7.1 \mathrm{Ma}$ (Figure $7 \mathrm{~d}$ ). Ages for all these samples are presented in Figure 8.

\subsection{Silurian Units}

Two foliated dacite samples from the units at the western end of our transect (Figure 2b) that are in faulted contact with the Ordovician rocks have been analyzed. Zircons from the two samples are usually euhedral in shape with clear zonation. Some of the zircons show recrystallized rims (Figures 7e and 7f). Sample $16 \mathrm{Smkr01}$ has a weighted mean zircon age at $419.6 \pm 6.3 \mathrm{Ma}$ with scatter beyond analytical error (mean square weighted deviation $=3.4$ ) and three older grains at 440,493 , and $3387 \mathrm{Ma}$ (Figure 7e and supporting information Data Set S4). Zircons from $16 \mathrm{Smkd01}$ have a non-Gaussian ${ }^{206} \mathrm{~Pb} /{ }^{238} \mathrm{U}$ age distribution, with the main peak age at $419.7 \pm 1.6 \mathrm{Ma}$, the second peak age at $388 \pm 3.7 \mathrm{Ma}$, and older ages at 444, 515, and 1079 Ma (Figure $7 \mathrm{f}$ and Data Set S4). The sizable spread of the apparent igneous ages of these two dacite samples show that they were probably affected by post-Silurian deformation when the zircons may have been variably recrystallized.

\section{Zircon Hf Isotopic Compositions}

Lu-Hf analyses were conducted on 14 zircon grains from the Triangle Formation, including 10 from TR04 and 4 from 16TR11 (Figure 9). Due to some of the dated zircons being too small (less than 40 um) to be analyzed by laser for $\mathrm{Hf}$, only nine Lu-Hf analyses were conducted on grains with $\mathrm{U}-\mathrm{Pb}$ ages, while other analyzed grains from TR04 have no direct ages. The youngest grain from TR04 (456 Ma) shows a negative initial $\varepsilon H f$ value at -10.91 . Other Cambrian to Precambrian zircons also record negative initial $\varepsilon H f$ values ranging from -1.25 to -7.12 . Those grains having no direct ages were calculated using the youngest grain age at 456 $\mathrm{Ma}$ and thereby show apparent initial $\varepsilon H f$ values ranging from -10.91 to +1.98 . Fourteen grains from WF01 (Weemalla Formation) were analyzed, including nine analyses on grains with no direct U-Pb ages. As this sample has a robust unimodal concordant ${ }^{206} \mathrm{~Pb} /{ }^{238} \mathrm{U}$ age at $450.5 \mathrm{Ma}$, this weighted mean age was used for the initial $\varepsilon H f$ calculation with values ranging from +9.39 to +11.19 .

\section{Discussion}

\subsection{Age Constraints of the Triangle Formation}

In the Rockley area, the Triangle Formation is dominated by quartz-rich siltstones and volcaniclastic rocks. In this area, the base is not exposed (Fowler \& Iwata, 1995). The top is constrained by conodont assemblages of late Darriwilian to early Gisbornian (462-457 Ma) age and is overlain by the Rockley volcaniclastic rocks. In the Goulburn area, the Triangle Formation is dominated by metamorphosed quartzose and lithic greywackes and black slate (Offenberg, 1974). Graptolites extracted from these rocks indicate an Eastonian age (453-448 Ma; Offenberg, 1974). In our transect at Bald Ridge, a metamorphosed quartz-rich sandstone (TR04) has a youngest detrital zircon age of 456 Ma defining the maximum age of deposition (Figure 10). Therefore, we suggest that the basal part of the Triangle Formation is likely to be dominated by quartz-rich sandstones and siltstones that are overlain by interbedded quartz siltstones and mafic volcaniclastic rocks 


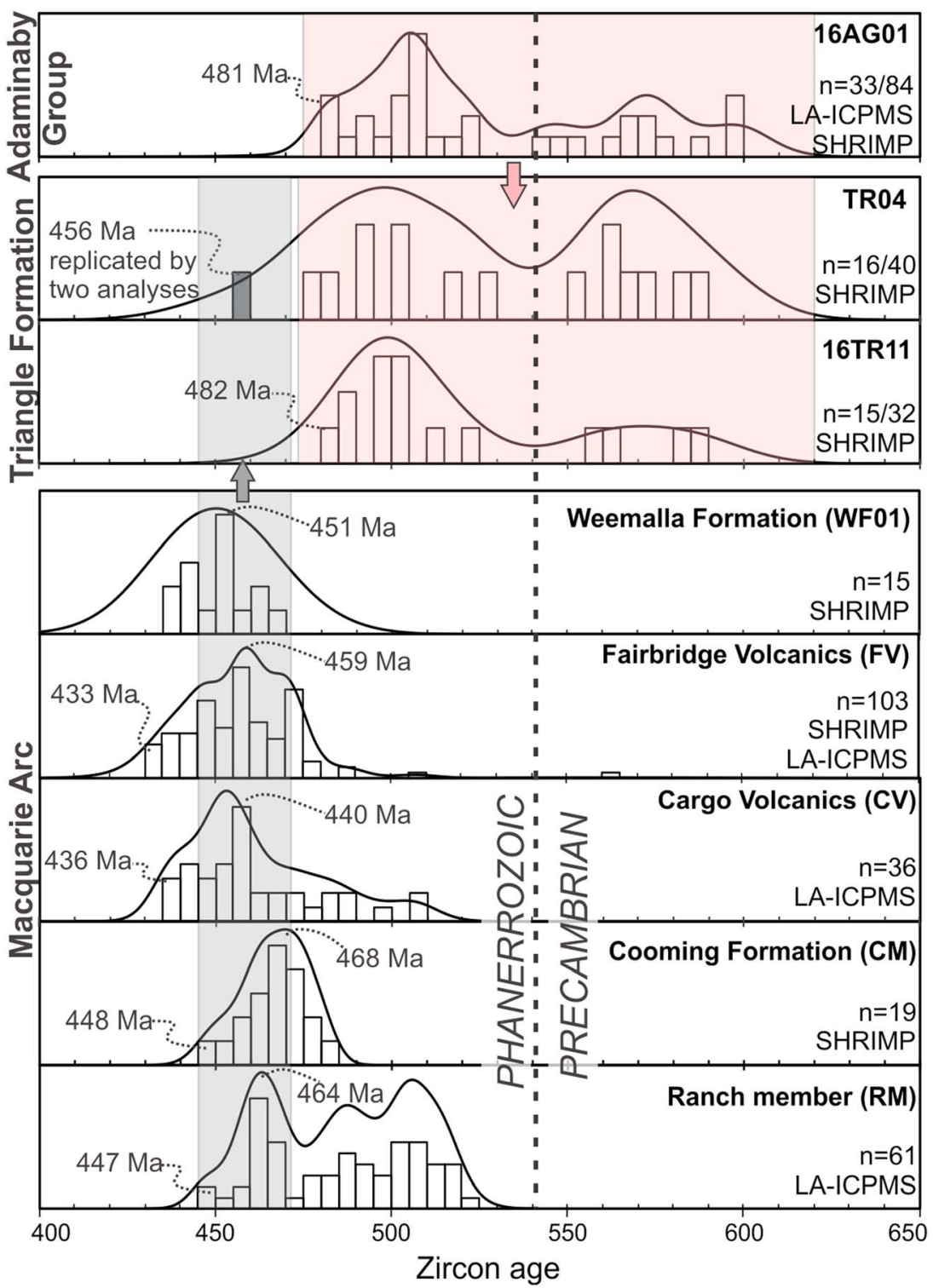

Figure 8. Detailed detrital zircon age results for the Adaminaby Group, Triangle Formation, and various formations within the Macquarie Arc. For samples 16AG01, TR04, and 16TR11, ages larger than $650 \mathrm{Ma}$ are not plotted in this diagram due to the limited age range of this figure $(n=$ number of analyses plotted in this diagram/number of total analyses). The complete plots are shown in Figure 7. The pink and gray arrows represent the possible sources of the Triangle Formation during different stages: The Early Ordovician to Precambrian source is from the Adaminaby Group, and the Middle Ordovician source is from the Macquarie Arc. Data sources: samples 16AG01, TR04, 16TR11, and WF01 are from this study; Cargo Volcanics (CV) is from Meffre et al. (2007); and sources of samples FV, CM, and RM can be found in Figure 3 captions.

(and chert) of late Darriwilian to early Gisbornian (462-457 Ma) age. The middle part of the formation is primarily fine-grained metamorphosed quartz-rich sandstones with the youngest age of $456 \mathrm{Ma}$, while the upper part is dominated by quartzose and lithic greywackes of Eastonian age (452-448 Ma; Figure 10). At Bald Ridge, the contact between the Triangle Formation and the underlying Adaminaby Group is marked by the presence of the distinct mafic schist unit that appears as mélange near the contact (Figure S2b).

Meffre et al. (2007) suggested that those metamorphosed Triangle Formation sandstones that are rich in mica are strongly altered quartz-poor volcaniclastic rocks. However, our mica quartz-rich metamorphosed sandstones (TR04 and 16TR11) yielded large numbers of pre-Ordovician zircons, which are unlikely to be 

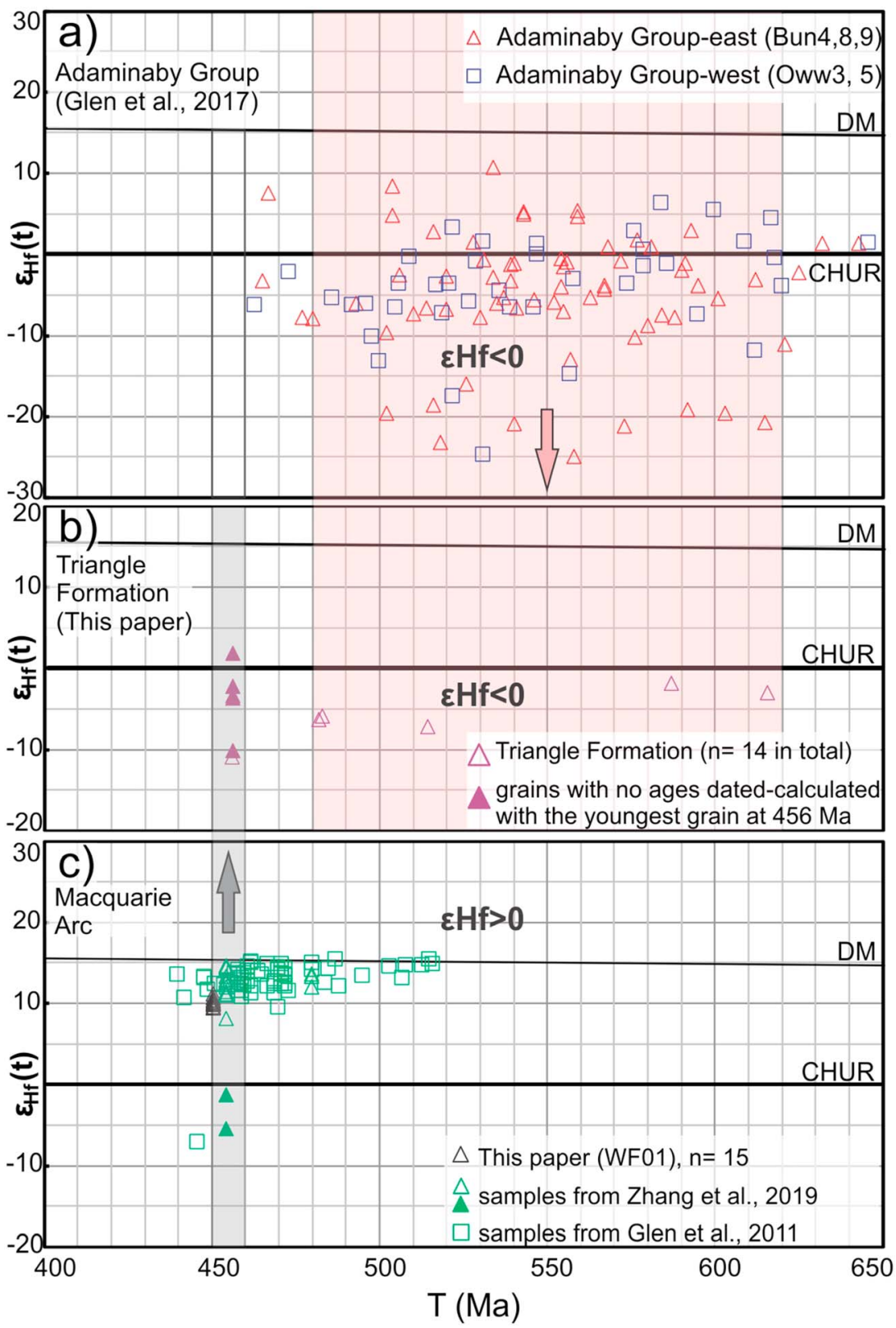

Figure 9. (a-c) Zircon Hf isotope results for the Triangle (TR04, 16TR11) and Weemalla formations (WF01) in comparison with the Adaminaby Group. The pink and gray arrows represent the sources of the Triangle Formation during different deposition periods. Data source: TR04, 16TR11, and WF01 (this study) and Adaminaby Group (Glen et al., 2017); other Macquarie Arc samples: Mitchell Formation and part of Fairbridge Volcanics (Zhang et al., 2019), Ranch Member, Cargo, and part of Fairbridge volcanics (Glen et al., 2011). Three Hf isotope analyses of Precambrian zircons from the Triangle Formation are not plotted in the above figure, which are at 929, 1995, and 3404 Ma with initial $\varepsilon H f$ at $-2.9,-7.2$, and -1.5 , respectively, due to limitation of the size of the figure.

derived from the unimodal, Ordovician volcaniclastic rocks of the Macquarie Arc. Instead, their age spectra are similar age to that of the Adaminaby Group, apart from the single 456-Ma grain (Figures 8 and 11). Most previous studies do not report any mixing of provenance between the Macquarie Arc volcanic rocks and the craton-derived quartz-rich turbidites (Colquhoun et al., 1999; Glen, 2005; Glen et al., 1998; Meffre et al., 2007). It is reported that the quartz-rich succession and the feldspathic volcaniclastic rocks are in faulted contact, but not interbedded, in the Rockley area (Meffre et al., 2007). However, Fergusson (1979) described lithofeldspathic sandstone and breccia in upper part of the Adaminaby Group interfingered 


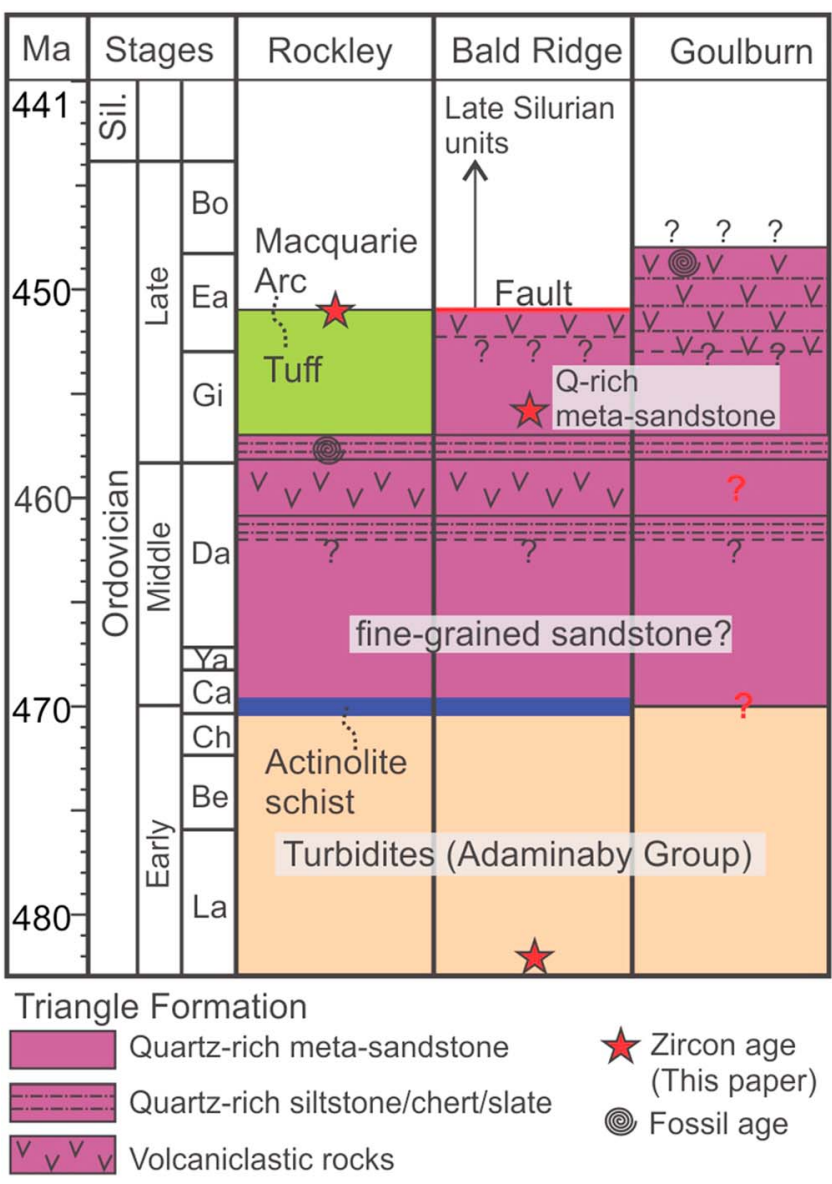

Figure 10. Proposed stratigraphy of the Triangle Formation. Fossil ages: conodont assemblages in Rockley area indicate the age range of late Darriwilian to early Gisbornian (462-457 Ma; Fowler \& Iwata, 1995; Murray \& Stewart, 2001); graptolites in Goulburn area indicate an Eastonian age (453-448 Ma; Offenberg, 1974). Notes: (1) The Macquarie Arc sample (WF01) with zircon age is not exactly from the Rockley area (Figures $1 \mathrm{~b}$ and 1c). This is a representative age of late Ordovician Macquarie Arc rocks including the Rockley Volcanics in the Rockley Area. (2) The red questions marks mean that there is no actinolite schist and Middle Ordovician volcanic rocks associated with Triangle Formation being reported yet in Goulburn area. The black question marks mean that the boundary is not clearly defined. with the lower part of the Sofala Volcanics (eastern part of the Macquarie Arc). In our transect, there is no clear boundary between quartz-rich sandstone and feldspar-rich volcaniclastic rocks, where both types of rocks have been deformed and are unconformably overlain by less deformed Siluro-Devonian felsic volcanic units (Figures $2 \mathrm{~b}$ and $2 \mathrm{c}$ ). During emplacement of the Macquarie Arc terrane, we propose that movement may have been partitioned between a zone of secondary faults, cutting through the Triangle Formation and dividing the quartz-rich sandstone and mafic volcaniclastic rocks. The existence of Ordovician-Silurian deformation has been identified by ${ }^{40} \mathrm{Ar} /{ }^{39} \mathrm{Ar}$ dating of mica from metamorphosed units of the Adaminaby Group, with ages at $~ 460-440$ Ma (Prendergast et al., 2011) or 455-445 Ma (Foster et al., 1999), which is consistent with the Benambran Orogeny (Glen, Meffre, et al., 2007).

The new data reported in this study suggest that the Triangle Formation is a Middle-Late Ordovician unit that is dominated by Gondwanan-derived quartz-rich sandstone in its lower part and is interbedded with Macquarie Arc-derived detritus toward the top (Figure 10). This is contrast to Percival et al. (2011), who proposed that the Triangle Formation is a Siluro-Devonian formation with exotic Ordovician blocks, chert, and Silurian limestone clasts. Importantly, though, at the western end of the Bald Ridge transect, the Siluro-Devonian dacite units are in faulted contact with the Triangle Formation and have ages at $\sim 420-388 \mathrm{Ma}$ (Figures $2 \mathrm{~b}$, 7e, and 7f). Thus, we suggest that the "Triangle Formation" with Ordovician and Silurian clasts reported by Percival et al. (2011) may have been within a fault zone between the Ordovician and Late Silurian units or from the unconformably overlying Silurian volcaniclastic units.

\subsection{Provenance and Setting of the Young Components of the Triangle Formation}

To constrain the age of the youngest components of the Triangle Formation, we have compiled the detrital zircon age spectra of the Triangle Formation with the Adaminaby Group located near the Macquarie Arc and also spectra of the Adaminaby Group from the western and eastern Albury-Bega units distant from the Macquarie Arc (Figure 11). For the 13 Adaminaby Group samples from the literature, there are some late Ordovician zircons (456-467 Ma), with no multiple analyses (e.g., AGM, AGO, Oww3,5, Mum1, and Bun8,9 in Figures 11 and 3). These youngest ages not verified by replicated analyses are considered suspect due to potential nondocumented loss of radiogenic $\mathrm{Pb}$. The second youngest grain ages of these samples are 473-486 Ma (Figure 3). There is no distinct age difference for the youngest detrital zircons in the Adaminaby Group from different areas, with the youngest populations ranging from 473 to $491 \mathrm{Ma}$. Sample TR04 from the middle unit of the Triangle Formation has a zircon age population largely like that of the Adaminaby Group but with one grain at $456 \mathrm{Ma}$ verified by duplicate analysis, which is the dominant age of zircons from younger, more evolved portions of the Macquarie Arc (Figures 8 and 10). Further, the Hf isotope composition (Figure 9) of the young grain (456 Ma) from TR04 has a negative initial $\mathrm{kHf}$ value $(-10.01)$. The reason for this is probably that the Macquarie Arc was proximal enough to the continent by $456 \mathrm{Ma}$, to produce magmatic zircons involving sources derived from the melting of Gondwanan detritus. This contention is supported by a few zircons with negative initial $\varepsilon H f$ values from the Cargo (Glen et al., 2011) and Fairbridge volcanics (Zhang et al., 2019) of the Macquarie Arc (Figure 9c). The older detrital components of the Triangle Formation resemble the Adaminaby Group indicating mixed detrital provenance (Figure 9).

The detrital source of the Triangle Formation (TR04) has a large Gondwanan input as found in the Adaminaby Group. This is reflected in the contrasting whole rock geochemistry characteristics of the 


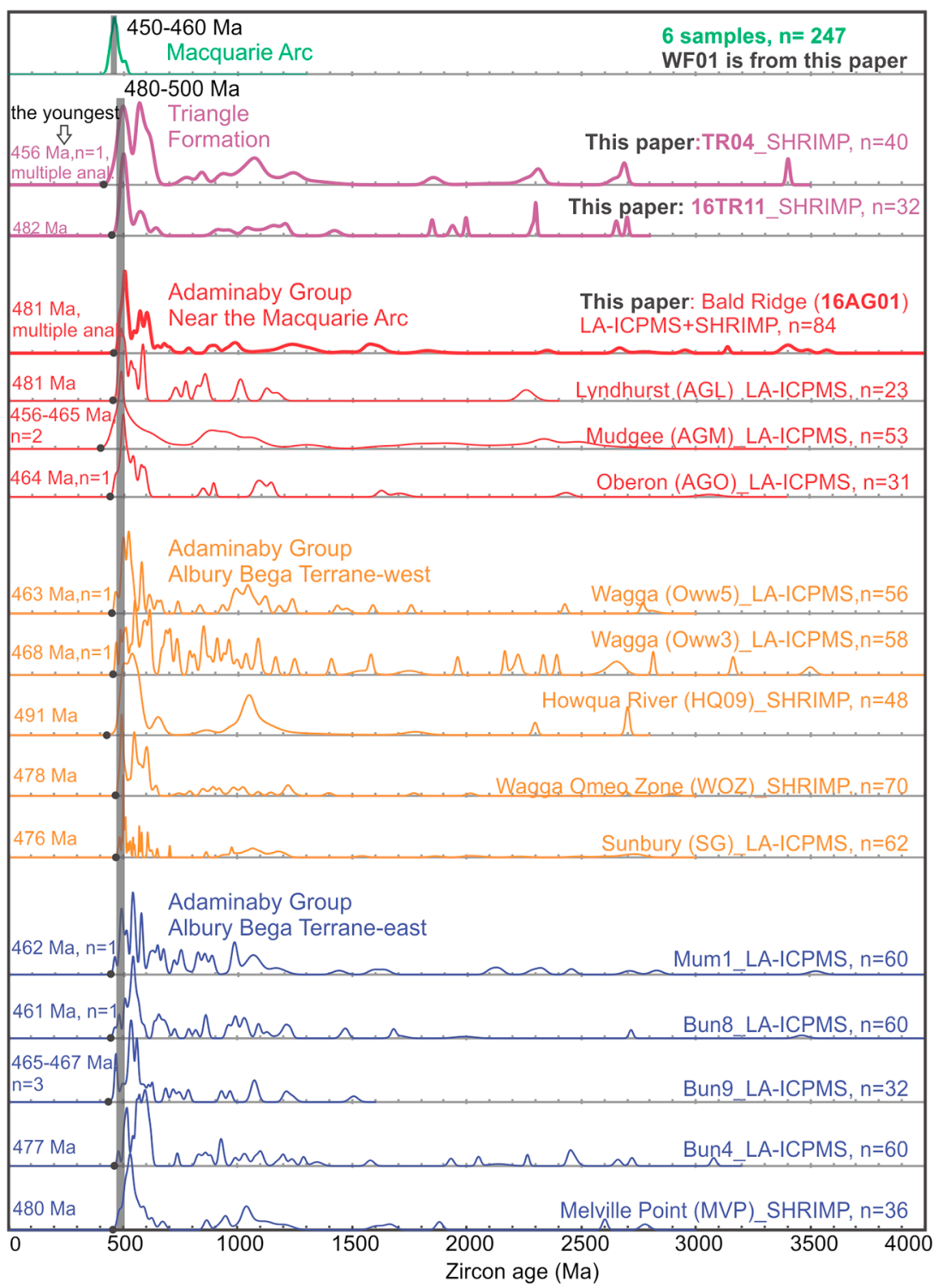

Figure 11. Zircon age comparison between the Triangle Formation and Adaminaby Group from the Lachlan Orogen (Sources of data can be found in Figure 3). The populations of zircon ages of the Triangle Formation and Adaminaby Group are similar, but the youngest deposition ages are different.

Triangle Formation and Adaminaby Group versus the Macquarie Arc. The $\Sigma$ REE signature of the Triangle Formation is between the Adaminaby Group and the Macquarie Arc but more similar to the Adaminaby Group (Figure 12a). Most of the Triangle Formation samples have negative Eu anomalies (Figure 12a); positive $\mathrm{U}, \mathrm{Th}$, and $\mathrm{Pb}$; and strongly negative $\mathrm{Sr}$ and $\mathrm{Ti}$ anomalies, similar to the Adaminaby Group samples (Figure 12b). Exceptions are sample 16TR15-1 from the upper part of the Triangle Formation and sample 16TR14, which have no obvious Eu and Sr negative anomalies and are similar to the Macquarie Arc samples (Figure 12). The tectonic setting diagram (Figure 5d) indicates a transitional trend of the Triangle Formation from passive margin to island arc setting.

In summary, the Triangle Formation is of mixed Gondwanan and Macquarie Arc provenance, with the youngest fossil ages of $\sim 448-462 \mathrm{Ma}$ and the youngest zircon age of $\sim 456 \mathrm{Ma}$, which from Hf isotope results indicates magmatic recycling of Gondwanan sources. The age of the Triangle Formation indicates that the originally juvenile arc was proximal to the Gondwanan continent by $\sim 448-462 \mathrm{Ma}$. This is consistent with the ${ }^{40} \mathrm{Ar} /{ }^{39} \mathrm{Ar}$ dating result of the Ordovician deformation on the Adaminaby Group at $450 \mathrm{Ma}$, which is 

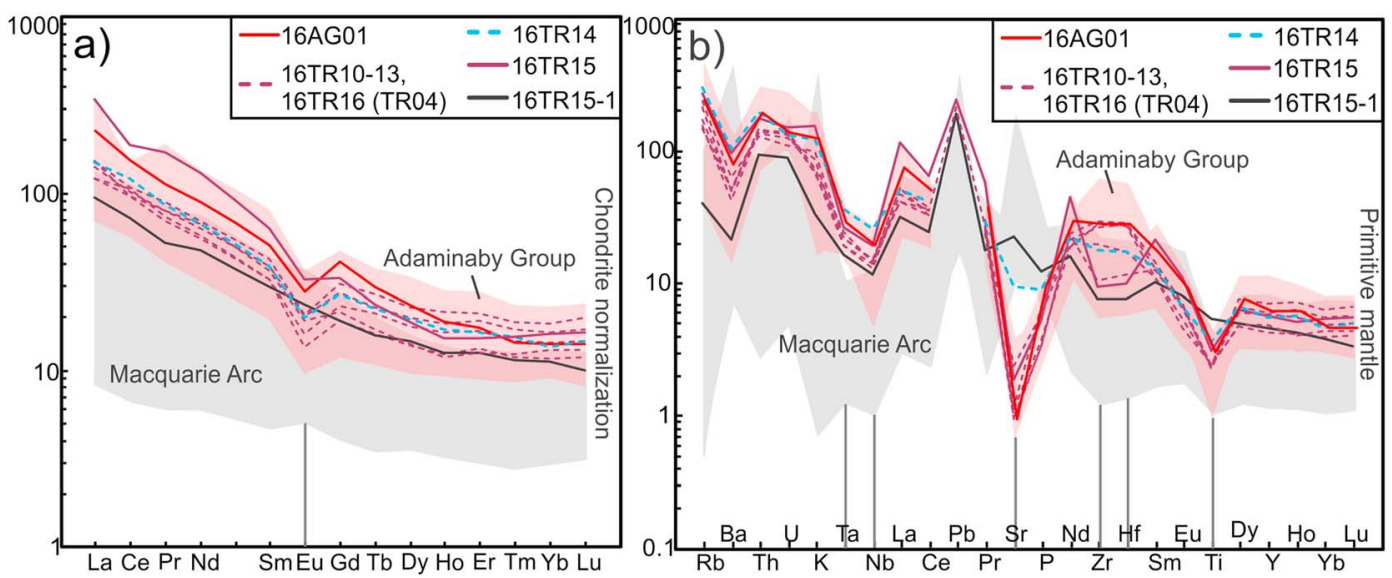

Figure 12. (a, b) Whole rock REE (chondrite normalized) and trace element (primitive mantle normalized) plots of the Adaminaby Group, Triangle Formation, and Macquarie Arc samples. Normalizing values are from Sun and McDonough (1989). Data sources: Adaminaby Group (Offler \& Fergusson, 2016) and Macquarie Arc (Zhang et al., 2019).

related to the emplacement of the Macquarie Arc against eastern Gondwana (Foster et al., 1999; Prendergast et al., 2011).

The apparent lack of mixing between the Macquarie Arc and continental sediments in terms of the detrital zircon record is probably because of the zircon-poor nature of the juvenile Macquarie Arc (Glen et al., 2011; Zhang et al., 2019), in comparison to the zircon-rich sediments of the Adaminaby Group (Glen et al., 2017). It is also likely due to the depositional setting of the Triangle Formation and the emplacement mechanism of the arc. Sandstones in convergent plate margins including backarc, forearc, and accretionary complex settings are usually dominated by arc-derived volcanic detritus (Aitchison \& Buckman, 2012; Marsaglia \& Ingersoll, 1992). The Triangle Formation is dominated by felsic components (Figures 5b and 5c) suggesting that it accumulated in a trench fill setting between the Gondwana continental margin and the approaching Macquarie Arc (Figure 13). This trench fill setting would be short lived considering the lack of mixing. The short duration of this setting might be caused by the sediment lubrication during subduction (Behr \& Becker, 2018).

\subsection{Origin, Formation, and Significance of the Mafic Schist}

The mafic schists between the Triangle Formation and Adaminaby Group (Figure 13) display geochemical signatures consistent with derivation from the basement of the Macquarie Arc (Figures 5 and 6). For instance, samples TR05A, TR05B, and TR05C fall in the andesite and basalt fields, which partly overlap the Macquarie Arc samples in the $\mathrm{Nb} / \mathrm{Y}-\mathrm{Zr} / \mathrm{TiO}_{2}$ diagram (Figure 5b). These samples have a relatively low $\mathrm{Mg}$ content than the depleted mantle but overlap with the gabbro cumulates structurally higher in the Macquarie Arc (Figure 6b). In the $\mathrm{Nb} / \mathrm{Yb}-\mathrm{Th} / \mathrm{Yb}$ diagram, these samples overlap with some of the Macquarie Arc samples in the oceanic arc setting (Figure 6). They also display similar (La/Yb)N values (2.89-3.98) to the mafic enclaves of the Macquarie Arc volcanic rocks (2.08-2.90; e.g., 16BY11i, 16FV02i, and 16FV02ii; supporting information Data Set S8). Thus, the protolith for these schists may have been gabbroic cumulates within the roots of the Macquarie Arc, which has been tectonized beyond recognition in the field.

The development of the schistose fabric was probably related to emplacement of the Macquarie Arc against eastern Gondwana during the resultant Benambran Orogeny (Glen, Meffre, et al., 2007). Alternatively, it may have been acquired during subduction before the emplacement (Figure 13b) and then thrusted over the continent when the arc was emplaced (Figure 13c). However, there is only one metamorphic event at upper greenschist facies identified in the schist samples (Figures $4 \mathrm{e}$ and $4 \mathrm{f}$ ), which is mirrored in the Triangle Formation indicated by the presence of biotite (Figures $4 \mathrm{~b}$ and $4 \mathrm{c}$ ). The Silurian dacite samples have rare metamorphic biotite but are dominated by a lower grade muscovite + chlorite assemblage (Figures $4 \mathrm{~g}$ and S5c). Thus, the upper greenschist to lower amphibolite facies metamorphism of the rocks may be related to the Late Ordovician-Early Silurian Benambran Orogeny during the collision of the Macquarie Arc and 


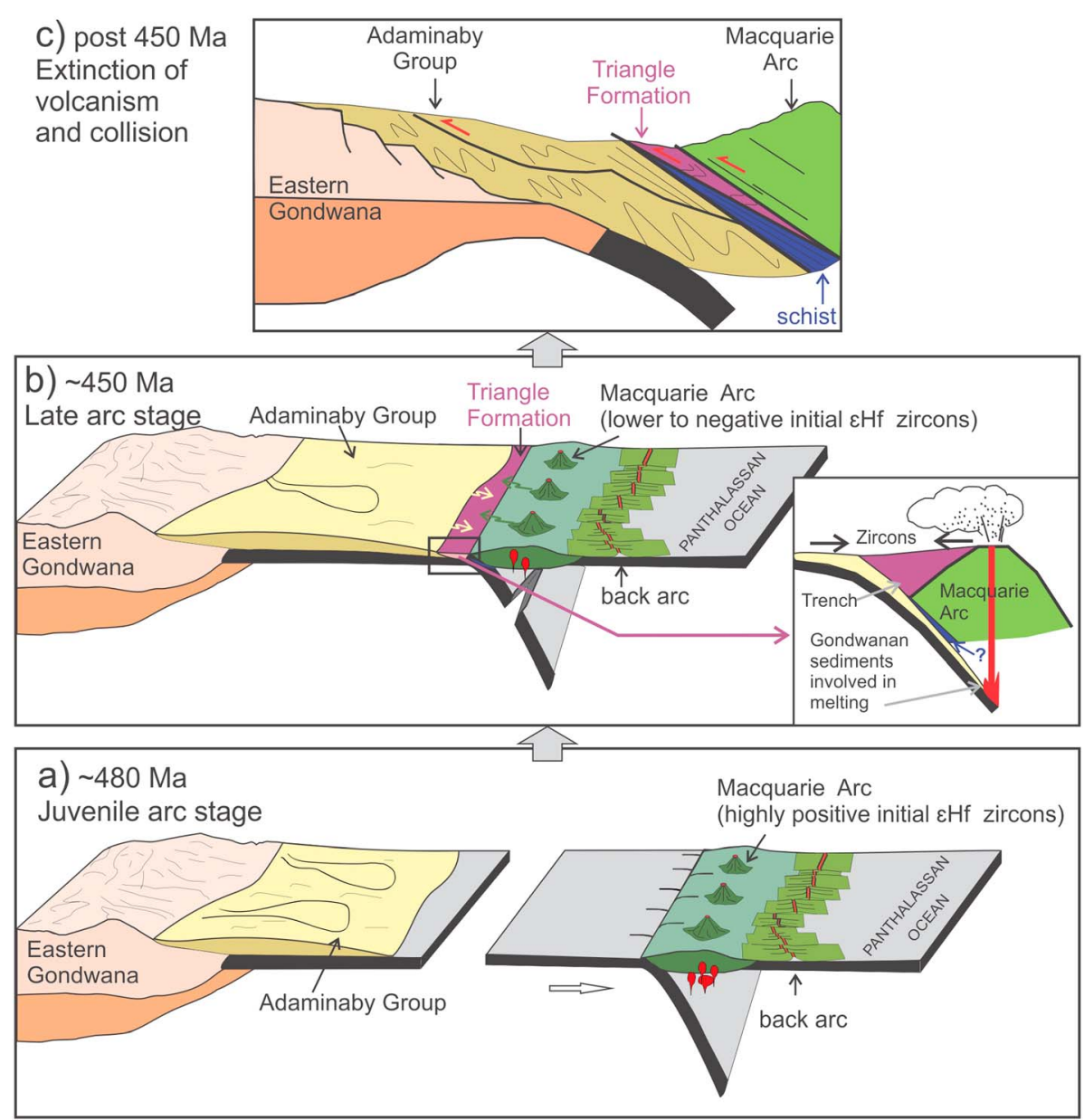

Figure 13. Schematic possible tectonic setting of the Triangle Formation during the emplacement of the Macquarie Arc. (a) The Macquarie Arc was initiated with no Gondwanan inheritance (after Aitchison \& Buckman, 2012 and Zhang et al., 2019). (b) In the middle-late arc stage, when the arc approached the eastern Gondwana continent, minor continental sediments contaminated the arc magma. In the trench, both continental and arc detritus contribute to the trench fill sediments. (c) Emplacement of the Triangle Formation (trench fill) and Macquarie Arc on top of the passive margin Adaminaby Group (Gondwana) during arc-continent collision results in the Benambran Orogeny. The mafic schist represents basement portions of the Macquarie Arc.

eastern Gondwana. The lower grade metamorphism (lower greenschist facies) identified in the Silurian dacite (muscovite + chlorite; Figure $4 \mathrm{~g}$ ) is probably related to post-Silurian Tabberabberan event at around $388 \mathrm{Ma}$ (Fergusson, 2017) indicated by the recrystallized zircon age (Figure 7f).

In general, the collision of an active island arc with a continental margin could be recorded in the trench fill sediments that develop adjacent to the two disparate terranes. This study highlights issues in the sedimentary rock record related to arc-continent collision mechanisms. In particular, the zircon signature from the oceanic arc will always be muted, due to the zircon-poor mafic-intermediate igneous rocks that dominate such arcs. Older oceanic terranes have the additional issue of being affected by overprinting deformation and removal of key evidence by erosion if they are on the overriding plate. Trench fill sediments sourced from both the continental margin and the arriving allochthonous island arc potentially provide key constraints to the nature and timing of these collisions.

\section{Conclusions}

1. The Triangle Formation structurally overlies the Adaminaby Group with the contact marked by mafic, actinolite-tremolite-talc schist, and localized zones of mélange. Stratigraphically, the Triangle 


\section{Acknowledgments}

This study is supported by the Geo Quest Research Centre, University of Wollongong, and the China Scholarship Council (201506400054). The U-Pb LA-ICP-MS analyses were funded by the National Key R \& D Program of China (2018YFC0604106) to Yang Song. We give our thanks to Chris Fergusson for constructive discussions. Shane Paxton is thanked for zircon separations of sample 16AG01 at ANU and to Tom McMahon for CL imaging on the SEM at UOW Electron Microscopy Centre. Paul Carr is thanked for whole rock major element XRF analyses and to Jose Abrantes for thin section making. Haifeng Li and Hong Chen are thanked for organizing the LA-ICP-MS analyses in China. We thank Paul Lennox and an anonymous reviewer providing constructive comments for improvement. The associated Editor Jason Ali is thanked for helpful comments and detailed editing. Meagan Kathleen Lowe and Jessica Walsh are thanked for proof reading.
Formation has a basal section dominated by quartz-rich sandstone with overlying interbedded quartzrich siltstone and mafic volcaniclastic rocks. The upper section is dominated by metamorphosed quartz-rich sandstone with overlying feldspar-rich greywackes in Bald Ridge and overlying quartzose and lithic greywackes in Goulburn.

2. The Triangle Formation is the product of trench fill sediments shortly before the emplacement of the Macquarie Arc onto the passive margin of the eastern Gondwana continent. The young (Late Ordovician) components of the Triangle Formation, indicated by the zircon age at $~ 456 \mathrm{Ma}$ and fossil ages at $\sim 448-462 \mathrm{Ma}$, are sourced from the Macquarie Arc.

3. The mafic schist is probably a sliver of tectonized gabbro cumulates of the Macquarie Arc, which was tectonically emplaced along a tectonic break separating the overriding Macquarie Arc from the underlying Adaminaby Group within the passive margin of Gondwana.

4. The arc-continent collision was initiated at $~ 448-462 \mathrm{Ma}$, based on the youngest components of the Triangle Formation, which are typically absent in the Adaminaby Group but match the age of younger parts of the arc, such as the $451-$ Ma Weemalla Formation.

\section{References}

Aitchison, J. C., \& Buckman, S. (2012). Accordion vs. quantum tectonics: Insights into continental growth processes from the Paleozoic of eastern Gondwana. Gondwana Research, 22(2), 674-680. https://doi.org/10.1016/j.gr.2012.05.013

Behr, W. M., \& Becker, T. W. (2018). Sediment control on subduction plate speeds. Earth and Planetary Science Letters, 502, 166-173. https://doi.org/10.1016/j.epsl.2018.08.057

Black, L. P., Kamo, S. L., Allen, C. M., Aleinikoff, J. N., Davis, D. W., Korsch, R. J., \& Foudoulis, C. (2003). TEMORA 1: A new zircon standard for Phanerozoic U-Pb geochronology. Chemical Geology, 200(1-2), 155-170. https://doi.org/10.1016/S00092541(03)00165-7

Bouma, A. H. (1962). Sedimentology of some Flysch deposits: A graphic approach to facies interpretation. Amsterdam: Elsevier.

Bouvier, A., Vervoort, J. D., \& Patchett, P. J. (2008). The Lu-Hf and Sm-Nd isotopic composition of CHUR: Constraints from unequilibrated chondrites and implications for the bulk composition of terrestrial planets. Earth and Planetary Science Letters, 273(1-2), 48-57. https:// doi.org/10.1016/j.epsl.2008.06.010

Cawood, P. A. (2005). Terra Australis Orogen: Rodinia breakup and development of the Pacific and Iapetus margins of Gondwana during the Neoproterozoic and Paleozoic. Earth-Science Reviews, 69(3-4), 249-279. https://doi.org/10.1016/j.earscirev.2004.09.001

Cawood, P. A., Kröner, A., Collins, W. J., Kusky, T. M., Mooney, W. D., \& Windley, B. F. (2009). Accretionary orogens through Earth history. Geological Society, London, Special Publications, 318(1), 1-36. https://doi.org/10.1144/SP318.1

Collins, W. J. (2002). Nature of extensional accretionary orogens. Tectonics, 21(4), 1024. https://doi.org/10.1029/2000TC001272

Colquhoun, G. P., L. Deyssing, Ballard, J. C., Hughes, K. S., \& Troedson, A. L. (2017). New South Wales zone 55 east seamless geology, version 1 [Digital Dataset].

Colquhoun, G. P., Fergusson, C. L., \& Tye, S. C. (1999). Provenance of early Palaeozoic sandstones, southeastern Australia. Part 2: Cratonic to arc switching. Sedimentary Geology, 125(3-4), 153-163. https://doi.org/10.1016/S0037-0738(99)00003-2

Compston, W., Williams, I., \& Meyer, C. (1984). U-Pb geochronology of zircons from lunar breccia 73217 using a sensitive high massresolution ion microprobe. Journal of Geophysical Research, 89(S02), B525-B534. https://doi.org/10.1029/JB089iS02p0B525

Crawford, A. J., Cooke, D. R., \& Fanning, C. (2007). Geochemistry and age of magmatic rocks in the unexposed Narromine, Cowal and Fairholme igneous complexes in the Ordovician Macquarie Arc, New South Wales. Australian Journal of Earth Sciences, 54(2-3), 243-271. https://doi.org/10.1080/08120090701221714

Crawford, A. J., Meffre, S., Squire, R. J., Barron, L. M., \& Falloon, T. J. (2007). Middle and Late Ordovician magmatic evolution of the Macquarie Arc, Lachlan Orogen, New South Wales. Australian Journal of Earth Sciences, 54(2-3), 181-214. https://doi.org/10.1080/ 08120090701227471

Crawford, A. J., Stevens, B. P. J., \& Fanning, M. (1997). Geochemistry and tectonic setting of some Neoproterozoic and Early Cambrian volcanics in western New South Wales. Australian Journal of Earth Sciences, 44(6), 831-852. https://doi.org/10.1080/ 08120099708728358

Cumming, G., \& Richards, J. (1975). Ore lead isotope ratios in a continuously changing Earth. Earth and Planetary Science Letters, 28(2), 155-171. https://doi.org/10.1016/0012-821X(75)90223-X

Davis, A. M., Aitchison, J. C., Luo, H., \& Zyabrev, S. (2002). Paleogene island arc collision-related conglomerates, Yarlung-Tsangpo suture zone, Tibet. Sedimentary Geology, 150(3-4), 247-273. https://doi.org/10.1016/S0037-0738(01)00199-3

Dewey, J. F. (2005). Orogeny can be very short. Proceedings of the National Academy of Sciences, 102(43), 15,286-15,293. https://doi.org/ $10.1073 /$ pnas.0505516102

Dickinson, W. R. (1985). Interpreting provenance relations from detrital modes of sandstones. In Provenance of arenites (pp. 333-361). New York, NY: Springer.

Fergusson, C. (1979). Pre-cleavage folds in the mid-Palaeozoic sequence near Capertee, New South Wales. Journal and Proceedings of the Royal Society of New South Wales, 112, 125-132.

Fergusson, C. (2003). Ordovician-Silurian accretion tectonics of the Lachlan Fold Belt, southeastern Australia. Australian Journal of Earth Sciences, 50(4), 475-490. https://doi.org/10.1046/j.1440-0952.2003.01013.x

Fergusson, C., \& Colquhoun, G. (1996). Early Palaeozoic quartz turbidite fan and volcaniclastic apron, Mudgee District, northeastern Lachlan fold belt, New South Wales. Australian Journal of Earth Sciences, 43(5), 497-507. https://doi.org/10.1080/ 08120099608728272

Fergusson, C. L. (2009). Tectonic evolution of the Ordovician Macquarie Arc, central New South Wales: Arguments for subduction polarity and anticlockwise rotation. Australian Journal of Earth Sciences, 56(2), 179-193. https://doi.org/10.1080/08120090802547017

Fergusson, C. L. (2017). Mid to late Paleozoic shortening pulses in the Lachlan Orogen, southeastern Australia: A review. Australian Journal of Earth Sciences, 64(1), 1-39. https://doi.org/10.1080/08120099.2017.1273257 
Fergusson, C. L., \& Colquhoun, G. P. (2018). Ordovician Macquarie Arc and turbidite fan relationships, Lachlan Orogen, southeastern Australia: Stratigraphic and tectonic problems. Australian Journal of Earth Sciences, 65(3), 303-333. https://doi.org/10.1080/ 08120099.2018.1425909

Fergusson, C. L., \& Fanning, C. M. (2002). Late Ordovician stratigraphy, zircon provenance and tectonics, Lachlan Fold Belt, southeastern Australia*. Australian Journal of Earth Sciences, 49(3), 423-436. https://doi.org/10.1046/j.1440-0952.2002.00929.x

Fergusson, C. L., Gray, D. R., \& Cas, R. A. (1986). Overthrust terranes in the Lachlan fold belt, southeastern Australia. Geology, 14(6), 519-522. https://doi.org/10.1130/0091-7613(1986)14<519:OTITLF $>2.0 . C O ; 2$

Fergusson, C. L., Henderson, R. A., \& Offler, R. (2017). Late Neoproterozoic to early Mesozoic sedimentary rocks of the Tasmanides, eastern Australia: Provenance switching associated with development of the East Gondwana active margin. In R. Mazumder (Ed.), Sediment Provenance (pp. 325-369). Netherlands: Elsevier.

Fergusson, C. L., Nutman, A. P., Kamiichi, T., \& Hidaka, H. (2013). Evolution of a Cambrian active continental margin: The DelamerianLachlan connection in southeastern Australia from a zircon perspective. Gondwana Research, 24(3-4), 1051-1066. https://doi.org/ 10.1016/j.gr.2013.03.006

Fergusson, C. L., \& VandenBerg, A. (1990). Middle Palaeozoic thrusting in the eastern Lachlan fold belt, southeastern Australia. Journal of Structural Geology, 12(5-6), 577-589. https://doi.org/10.1016/0191-8141(90)90075-A

Gray, D., \& Foster, D. (2004). Tectonic evolution of the Lachlan Orogen, southeast Australia: Historical review, data synthesis and modern perspectives. Australian Journal of Earth Sciences, 51(6), 773-817. https://doi.org/10.1111/j.1400-0952.2004.01092.x

Foster, D. A., Gray, D. R., \& Bucher, M. (1999). Chronology of deformation within the turbidite-dominated, Lachlan orogen: Implications for the tectonic evolution of eastern Australia and Gondwana. Tectonics, 18(3), 452-485. https://doi.org/10.1029/1998TC900031

Fowler, T., \& Iwata, K. (1995). Darriwilian-Gisbornian conodonts from the Triangle Group, Triangle Creek area, New South Wales. Australian Journal of Earth Sciences, 42(2), 119-122. https://doi.org/10.1080/08120099508728184

Glen, R. A. (1992). Thrust, extensional and strike-slip tectonics in an evolving Palaeozoic orogen-A structural synthesis of the Lachlan Orogen of southeastern Australia. Tectonophysics, 214(1-4), 341-380. https://doi.org/10.1016/0040-1951(92)90205-K

Glen, R. A. (2005). The Tasmanides of eastern Australia. Geological Society, London, Special Publications, 246(1), 23-96. https://doi.org/ 10.1144/gsl.sp.2005.246.01.02

Glen, R. A. (2013). Refining accretionary orogen models for the Tasmanides of eastern Australia. Australian Journal of Earth Sciences, 60(3), 315-370. https://doi.org/10.1080/08120099.2013.772537

Glen, R. A., Belousova, E., \& Griffin, W. L. (2016). Different styles of modern and ancient non-collisional orogens and implications for crustal growth: A Gondwanaland perspective. Canadian Journal of Earth Sciences, 53(11), 1372-1415. https://doi.org/10.1139/cjes-20150229

Glen, R. A., Crawford, A. J., Percival, I. G., \& Barron, L. M. (2007). Early Ordovician development of the Macquarie Arc, Lachlan Orogen, New South Wales. Australian Journal of Earth Sciences, 54(2-3), 167-179. https://doi.org/10.1080/08120090601146797

Glen, R. A., Fitzsimons, I. C. W., Griffin, W. L., \& Saeed, A. (2017). East Antarctic sources of extensive Lower-Middle Ordovician turbidites in the Lachlan Orogen, southern Tasmanides, eastern Australia. Australian Journal of Earth Sciences, 64(2), 143-224. https://doi.org/ 10.1080/08120099.2017.1273256

Glen, R. A., Meffre, S., \& Scott, R. J. (2007). Benambran Orogeny in the Eastern Lachlan Orogen, Australia. Australian Journal of Earth Sciences, 54(2-3), 385-415. https://doi.org/10.1080/08120090601147019

Glen, R. A., Percival, I. G., \& Quinn, C. D. (2009). Ordovician continental margin terranes in the Lachlan Orogen, Australia: Implications for tectonics in an accretionary orogen along the east Gondwana margin. Tectonics, 28, TC6012. https://doi.org/10.1029/2009tc002446

Glen, R. A., Saeed, A., Quinn, C. D., \& Griffin, W. L. (2011). U-Pb and Hf isotope data from zircons in the Macquarie Arc, Lachlan Orogen Implications for arc evolution and Ordovician palaeogeography along part of the east Gondwana margin. Gondwana Research, 19(3), 670-685. https://doi.org/10.1016/j.gr.2010.11.011

Glen, R. A. W., Walshe, J. L., Barron, L. M., \& Watkins, J. J. (1998). Ordovician convergent-margin volcanism and tectonism in the Lachlan sector of east Gondwana. Geology, 26(8), 751-754. https://doi.org/10.1130/0091-7613(1998)026<0751:OCMVAT>2.3.CO;2

Hiess, J., Bennett, V. C., Nutman, A. P., \& Williams, I. S. (2009). In situ U-Pb, O and Hf isotopic compositions of zircon and olivine from Eoarchaean rocks, West Greenland: New insights to making old crust. Geochimica et Cosmochimica Acta, 73(15), 4489-4516. https://doi. org/10.1016/j.gca.2009.04.019

Huang, C.-Y., Chen, W.-H., Wang, M.-H., Lin, C.-T., Yang, S., Li, X., et al. (2018). Juxtaposed sequence stratigraphy, temporal-spatial variations of sedimentation and development of modern-forming forearc Lichi Mélange in North Luzon Trough forearc basin onshore and offshore eastern Taiwan: An overview. Earth-Science Reviews, 182, 102-140. https://doi.org/10.1016/j.earscirev.2018.01.015

Jackson, S. E., Pearson, N. J., Griffin, W. L., \& Belousova, E. A. (2004). The application of laser ablation-inductively coupled plasma-mass spectrometry to in situ U-Pb zircon geochronology. Chemical Geology, 211(1-2), 47-69. https://doi.org/10.1016/j.chemgeo.2004.06.017

Jagoutz, E., Palme, H., Baddenhausen, H., Blum, K., Cendales, M., Dreibus, G., et al. (1979). The abundances of major, minor and trace elements in the Earth's mantle as derived from primitive ultramafic nodules. Paper presented at the 10th Lunar and Planetary Science Conference, Houston, Texas.

Leitch, E., \& Scheibner, E. (1987). Stratotectonic terranes of the eastern Australian Tasmanides. In Terrane accretion and orogenic belts (Vol. 19, pp. 1-19). Washington, DC: American Geophysical Union. https://doi.org/10.1029/GD019p0001

Lu, Y. (2004). GeoKit-A geochemical toolkit for Microsoft Excel. Geochimica, 33, 459-464.

Ludwig, K. R. (2003). User's manual for isoplot 3.00. A geochronlogical toolkit for microsoft excel, Special Publication (Vol. 4, pp. 25-32). Berkeley: Berkeley Geochronology Center.

Marsaglia, K. M., \& Ingersoll, R. V. (1992). Compositional trends in arc-related, deep-marine sand and sandstone: A reassessment of magmatic-arc provenance. Geological Society of America Bulletin, 104(12), 1637-1649. https://doi.org/10.1130/00167606(1992)104<1637:CTIARD>2.3.CO;2

Meffre, S., Scott, R. J., Glen, R. A., \& Squire, R. J. (2007). Re-evaluation of contact relationships between Ordovician volcanic belts and the quartz-rich turbidites of the Lachlan Orogen. Australian Journal of Earth Sciences, 54(2-3), 363-383. https://doi.org/10.1080/ 08120090701221680

Moresi, L., Betts, P. G., Miller, M. S., \& Cayley, R. A. (2014). Dynamics of continental accretion. Nature, 508(7495), 245-248. https://doi.org/ 10.1038 /nature13033

Murray, S., \& Stewart, I. (2001). Palaeogeographic significance of Ordovician conodonts from the Lachlan Fold Belt, southeastern Australia. Historical Biology, 15(1-2), 145-170. https://doi.org/10.1080/10292380109380588

Norrish, K., \& Chappell, B. W. (1977). X-ray fluorescence spectrometry. In Physical Methods in Determinative Mineralogy (2nd ed., pp. 201-272). London: Academic Press. 
Nutman, A. P., Bennett, V. C., Friend, C. R., Jenner, F., Wan, Y., \& Liu, D. (2009). Eoarchaean crustal growth in West Greenland (Itsaq Gneiss Complex) and in northeastern China (Anshan area): Review and synthesis. Geological Society, London, Special Publications, 318(1), 127-154. https://doi.org/10.1144/SP318.5

Offenberg, A. (1974). 1: 250,000 Geological series explanatory notes. Geological Survey of New South Wales: Goulburn.

Offler, R., \& Fergusson, C. L. (2016). Proto-Pacific-margin source for the Ordovician turbidite submarine fan, Lachlan Orogen, southeast Australia: Geochemical constraints. Sedimentary Geology, 334, 53-65. https://doi.org/10.1016/j.sedgeo.2016.01.011

Pearce, J. A. (1982). Trace element characteristics of lavas from destructive plate boundaries. In R. S. Thorpe (Ed.), Andesites: Orogenic Andesites and Related Rocks (Vol. 8, pp. 525-548). New York: John Wiley and Sons.

Percival, I., \& Glen, R. (2007). Ordovician to earliest Silurian history of the Macquarie Arc, Lachlan Orogen, New South Wales. Australian Journal of Earth Sciences, 54(2-3), 143-165. https://doi.org/10.1080/08120090601146789

Percival, I. G., Quinn, C. D., \& Glen, R. A. (2011). A review of Cambrian and Ordovician stratigraphy in New South Wales. In Quarterly Notes of the Geological Survey of New South Wales (Vol. 137, pp. 1-39). Maitland, New South Wales: Geological Survey of New South Wales.

Pogson, D., \& Watkins, J. (1998). Bathurst 1: 250000 Geological Sheet S1/55-8: Explanatory Notes. Sydney: Geological Survey of New South Wales.

Prendergast, E., Offler, R., Phillips, D., \& Zwingmann, H. (2011). ${ }^{40} \mathrm{Ar} /{ }^{39} \mathrm{Ar}$ and K-Ar ages: Early Paleozoic metamorphism and deformation in the Narooma accretionary complex, NSW. Australian Journal of Earth Sciences, 58(1), 21-32. https://doi.org/10.1080/ 08120099.2011.534506

Roser, B., \& Korsch, R. (1986). Determination of tectonic setting of sandstone-mudstone suites using content and ratio. The Journal of Geology, 94(5), 635-650. https://doi.org/10.1086/629071

Roser, B., \& Korsch, R. (1988). Provenance signatures of sandstone-mudstone suites determined using discriminant function analysis of major-element data. Chemical Geology, 67(1-2), 119-139. https://doi.org/10.1016/0009-2541(88)90010-1

Sengör, A. C., \& Natal'In, B. A. (1996). Turkic-type orogeny and its role in the making of the continental crust. Annual Review of Earth and Planetary Sciences, 24(1), 263-337. https://doi.org/10.1146/annurev.earth.24.1.263

Sláma, J., Košler, J., Condon, D. J., Crowley, J. L., Gerdes, A., Hanchar, J. M., et al. (2008). Plešovice zircon-A new natural reference material for U-Pb and $\mathrm{Hf}$ isotopic microanalysis. Chemical Geology, 249(1-2), 1-35. https://doi.org/10.1016/j.chemgeo.2007.11.005

Squire, R. J., Campbell, I. H., Allen, C. M., \& Wilson, C. J. (2006). Did the Transgondwanan Supermountain trigger the explosive radiation of animals on Earth? Earth and Planetary Science Letters, 250(1-2), 116-133. https://doi.org/10.1016/j.epsl.2006.07.032

Stanton, R. (1956). The Palaeozoic rocks of the Wiseman's Creek-Burraga area, NSW. Journal and Proceedings of the Royal Society of New South Wales, 89, 131-145.

Sun, S.-S., \& McDonough, W.-S. (1989). Chemical and isotopic systematics of oceanic basalts: Implications for mantle composition and processes. Geological Society, London, Special Publications, 42(1), 313-345. https://doi.org/10.1144/GSL.SP.1989.042.01.19

Taylor, S. R., \& McLennan, S. (1981). The composition and evolution of the continental crust: Rare earth element evidence from sedimentary rocks. Philosophical Transactions of the Royal Society of London. Series A, 301(1461), 381-399. https://doi.org/10.1098/ rsta.1981.0119

Thomas, O., \& Pogson, D. (2012). Goulburn 1: 250000 geological sheet, SI/55-12: Explanatory notes. NSW: Department of Trade and Investment, Regional Infrastructure and Services.

Van Achterbergh, E., Ryan, C. G., Jackson, S. E., \& Griffin, W. L. (2001). Data reduction software for LA-ICP-MS. In P. J. Sylvester (Ed.), Laser Ablation-ICP-Mass Spectrometry in the Earth Sciences: Principles and Applications, Mineralog (Vol. 29, pp. 239-243). Ottawa, Ontario, Canada.

VandenBerg, A., \& Stewart, I. (1992). Ordovician terranes of the southeastern Lachlan Fold Belt: Stratigraphy, structure and palaeogeographic reconstruction. Tectonophysics, 214(1-4), 159-176. https://doi.org/10.1016/0040-1951(92)90195-C

Von Hagke, C., Philippon, M., Avouac, J.-P., \& Gurnis, M. (2016). Origin and time evolution of subduction polarity reversal from plate kinematics of Southeast Asia. Geology, 44(8), 659-662. https://doi.org/10.1130/G37821.1

Williams, I. S. (1998). U-Th-Pb geochronology by ion microprobe. In Reviews in Economic Geology (Vol. 7, pp. 1-35). Toronto: The Society.

Winchester, J., \& Floyd, P. (1977). Geochemical discrimination of different magma series and their differentiation products using immobile elements. Chemical Geology, 20, 325-343. https://doi.org/10.1016/0009-2541(77)90057-2

Woodhead, J. D., \& Hergt, J. M. (2005). A preliminary appraisal of seven natural zircon reference materials for in situ Hf isotope determination. Geostandards and Geoanalytical Research, 29(2), 183-195. https://doi.org/10.1111/j.1751-908X.2005.tb00891.x

Zhang, Q., Buckman, S., Bennett, V. C., \& Nutman, A. (2019). Inception and early evolution of the Ordovician Macquarie Arc of Eastern Gondwana margin: Zircon U-Pb-Hf evidence from the Molong Volcanic Belt, Lachlan Orogen. Lithos, 326, 513-528. 